IZA DP No. 6018

Statistical Analysis of Landmine Fatalities in Kurdistan

Almas Heshmati

Nabaz T. Khayyat

October 2011

Forschungsinstitut zur Zukunft der Arbeit Institute for the Study of Labor 


\title{
Statistical Analysis of Landmine Fatalities in Kurdistan
}

\author{
Almas Heshmati \\ Korea University \\ and IZA \\ Nabaz T. Khayyat \\ Ministry of Agriculture, Iraq
}

\section{Discussion Paper No. 6018 \\ October 2011}

\author{
IZA \\ P.O. Box 7240 \\ 53072 Bonn \\ Germany \\ Phone: +49-228-3894-0 \\ Fax: +49-228-3894-180 \\ E-mail: iza@iza.org
}

\begin{abstract}
Any opinions expressed here are those of the author(s) and not those of IZA. Research published in this series may include views on policy, but the institute itself takes no institutional policy positions.

The Institute for the Study of Labor (IZA) in Bonn is a local and virtual international research center and a place of communication between science, politics and business. IZA is an independent nonprofit organization supported by Deutsche Post Foundation. The center is associated with the University of Bonn and offers a stimulating research environment through its international network, workshops and conferences, data service, project support, research visits and doctoral program. IZA engages in (i) original and internationally competitive research in all fields of labor economics, (ii) development of policy concepts, and (iii) dissemination of research results and concepts to the interested public.
\end{abstract}

IZA Discussion Papers often represent preliminary work and are circulated to encourage discussion. Citation of such a paper should account for its provisional character. A revised version may be available directly from the author. 
IZA Discussion Paper No. 6018

October 2011

\title{
ABSTRACT
}

\section{Statistical Analysis of Landmine Fatalities in Kurdistan}

This study analyzes mines and unexploded ordnance (UXO) victim data in the Kurdistan Region of Iraq during the period of the 1960s to 2005. In addition to descriptive analysis of the data, we use regression analysis to identify the determinants of the probability of getting killed by a mine or UXO and to estimate the determinants impacts. The rates of killed and injured victims are explained using a set of socioeconomic variables. Since the data is repeated cross sections in which individuals are observed when they are subjected to accident and in order to account for the dynamic aspect of the process and heterogeneity by location, we create pseudo panel data where districts are observed over the entire study period forming almost a balanced panel data. This allows for analysis of both heterogeneity and dynamics across locations and over time, as well as to control for unobserved location and time effects. The result can be useful in planning, monitoring, and resource allocation for mine action and labor market programmes and rehabilitation activities.

JEL Classification: C23, C42, H56, J15, N45

Keywords: landmine, unexploded ordinance, pseudo panel data, security and war, rehabilitation, Kurdistan

Corresponding author:

\author{
Almas Heshmati \\ Department of Food and Resource Economics \\ College of Life Sciences and Biotechnology \\ Korea University, East Building Room \#217 \\ Anam-dong Seongbuk-gu \\ Seoul 136-713 \\ Korea \\ E-mail: heshmati@korea.ac.kr
}




\section{Introduction}

The explosion of all kinds of mines and unexploded ordnance (UXO) will cause death or injury to humans and animals. In addition, it causes defects such as amputation and paralysis, which in turn lead to strong psychological, social, and economic effects. These effects are on the individual, family, and society and will turn people with disability and impairment into persons unable to work, walk, or move. It is well known that, despite the occurrence of daily incidents in many places around the world, the full impact will start after the return of normal life to the rural contaminated areas. Thus, the real impact is expected to take place following the return of the people to their villages and resuming their normal daily life activities such as agriculture and animal husbandry, where shepherds and peasants suffer the most. Another area that subjects people to danger is when the maintenance and rehabilitation of damaged infrastructure starts in the remote areas that are affected by massive deployment of mines and UXOs.

The Kurdistan Region is one of the major mines and UXO densely contaminated area. The number of killed per 1,000 population varies in the interval 0.27 and 58.83 among the different districts. The number and density of mines and UXOs in the region is not less if we compare that with other heavily mine-affected countries. Cambodia, for example, reported 600 victims per month, and the proportion of people with disabilities is 1 to 231 of the population. The corresponding numbers in Afghanistan is 500 victims in a week. Statistics show that there are more than 75,000 victims in Angola that are disabled by mines and UXOs ${ }^{1}$. It is believed that laying landmines in Iraq in general dated back to the 1940s, but it was sporadic and it did not appear to influence the civilian life comprehensively. However, its real beginning was from conflicts between the Iraqi army led by Saddam's regime and the Kurdish liberation forces (Peshmarga). Although the number of landmines was limited, it had serious consequences on the citizens. The process of laying the landmines continued by the Iraqi regime on the roads and axes, in the agriculture lands, around spring water sources, and other places aimed to limit the movement of the Peshmarga.

In the Kurdistan Region of Iraq with a population of nearly five million, mines were laid during four distinct phases. The first phase started in the mid-1970s to subdue Kurdish resistance movements operating in rural areas. The second phase was during the Iraq-Iran war in 1980s, when the number of landmines increased dramatically along the border with Iran. The third phase was the Gulf War when mines were laid along the border with Turkey. The fourth phase was related to the years from the end of the Gulf War, when Kurdish factions used landmines against each other. ${ }^{2}$ Thus, the Kuwait-related Gulf War, the invasion of Iraq by allied forces, and the Iraqi government's hostile assimilation policy resulted in laying a huge number of landmines across the border, especially within the Kurdish territories in the north. The Iraqi army has knowledge about the mines and the risks associated with them and it has access to equipment to clear the minefields. In

\footnotetext{
${ }^{1}$ International Campaign to Ban Landmines, Landmine Monitor Report 2009. Available at http://www.icbl.org

${ }^{2}$ U.S. Department of State, Hidden Killers: The Global Problem with Uncleared Landmines, 1993; Hidden Killers: The Global Landmine Crisis, 1998.
} 
general, the armed forces laid mines to depopulate specific regions. Therefore, they are reluctant to supply minefield maps to mine-clearing agencies or to participate in the clearing activities.

This study attempts to analyze mines and UXO victim data in the Kurdistan Region of Iraq during the period of the 1960s to 2005. In addition to descriptive analysis of the data, we use panel data regression analysis to identify the determinants of the probability of getting killed by mine/UXO and to estimate the determinants' impacts. Variations in the rates of killed and injured victims are explained using a set of socioeconomic variables. Since the data is repeated cross sections in which individuals are observed when they are subjected to accident and in order to account for the dynamic aspect of the process and heterogeneity by regional location, we create pseudo panel data where districts are observed over the entire study period. This allows for analysis of both heterogeneity and dynamics across locations and over time, as well as for control of unobserved location and time effects. The result can be useful to regional governments and nongovernmental organizations (NGOs) in planning, monitoring, and resource allocation for mine action and rehabilitation activities.

The rest of the paper is organized as follows. A brief review of the literature is provided in Section 2. In Section 3 and 4 we describe the repeated cross-sectional data and its transformed pseudo panel data. The model is outlined in Section 5, and the result is analyzed in Section 6. In Section 7 we discuss the socioeconomic, psychological, and overall impacts on health and well-being of the mine/UXO victims. The final section summarizes this study.

\section{Review of the Literature on Landmines}

To the best of our knowledge, little academic research has been published regarding factors determining the occurrence of landmine deaths and injuries or analysis of landmine accident risk factors at the community level (see also Krug et al., 1998). According to Ascherio et al. (1995), evidence based on hospital and household surveys showed that the return of civilians to landmine-contaminated areas, their touching of the mines, and their engaging in agriculture will increase the possibility of landmine accidents, in addition to de-mining activities during mine clearance. Regarding the activity of the mine victims at the time of accidents, Roberts and Williams (1995) concluded that most of the victims were injured while walking in mine-suspected areas. Shabila et al. (2010) analyzed the characteristics of hospitalized landmine injured patients in the Erbil governorate of Kurdistan. They found the need to examine the reasons behind handling explosives. Jahunlu et al. (2002). through investigating mortality in landmine accidents in Iran, found that most fatalities seemingly occurred in the pre-hospital setting.

Other research investigated the gender aspect of landmine accidents. Berthiaume (2003) explained that men and women have different mobility patterns, and hence they have different exposure and vulnerability to mines and UXOs. Women will most likely be exposed to landmine accidents while gathering wood and fuel or water, while men will be exposed while farming and travelling on public roads. A report by Bottomly (2003) 
showed that $61 \%$ of the victims in Cambodia are men and boys who mostly are exposed to mine risk. The pattern is similar in different parts of the world where elements of age and gender are observed in most surveys related to landmines. In a recent study, Bendinelli (2009) compared the impact of explosive remnants in rural Cambodia. Results show that $26.4 \%$ of the victims were children, predominately female, who sustained the more severe injuries.

Quesada (1998) reported on how the ripple effects of war and its aftermath are felt even after being mediated by time, space, and social status. Through a case study of a Nicaraguan boy and his natal family, Quesada argued that the legacy of war, structural violence, and endemic poverty are chronic. The impact of trauma and trauma care parameters on chronic pain in landmine accident survivors in Cambodia and Kurdistan shows high levels of chronic pain more than one year after the accident. Injury severity and primary trauma care have effects on chronic pain. Patient's loss of income is correlated with chronic pain syndromes (Husum et al., 2002). Champion et al. (1989) presented revised versions of trauma scores for use in outcome predictions and evaluations of patients with serious head injuries.

Analysis of the direct and indirect consequences of landmines on public health shows that landmines constitute a major public health problem in the world (Kakar et al., 1996). A number of measures and strategies are presented to prevent accidents and to increase the effect of treatment and rehabilitation programs. The environmental health consequences of anti-personnel landmines globally were reviewed by Newman and Mercer (2000). They recommended political efforts to ban the use of landmines. Husum et al. (2002) reported that the economic standing of the victim's family deteriorated after the accident. The social cost of landmines differs across countries suffering from landmines. Anderson et al.'s results showed that landmines undermine the economy and food security in affected countries, and the expense of medical care and rehabilitation adds economic disability to the physical burden (1995).

Concerning the economics of landmine clearance, Harris (2000) presented a cost-benefit analysis of landmine clearance in Cambodia and the alternative use of official development assistance resources. Harris arrived at the conclusion that costs are far greater than benefits in the low income areas; therefore, efforts should be made in the areas of de-mining technology efficiency rather than de-mining itself. Finally, Paterson (2001), in a commentary, criticized the Harris model, conclusion, and policy recommendations. The author suggested a reassessment to assure better accountability and a more balanced approach to the clearance of agricultural land and pasture land with high priority for the rural population. Mine clearance in extremely poor countries is justified in cost-benefit terms if the programs are well managed; for example, if productivity increases incrementally, if clearance efforts are well targeted, and if the programs are coordinated with rural development programs. 


\section{The Pseudo Panel Data Methodology}

The landmine data used in this study is originally repeated cross-sectional data collected on a yearly basis. The observed individuals are those subjected to landmine accidents, and the data contains individual and environmental characteristics. Since the data contains primarily information about the accidents and not much about post-accident measures, it provides little information useful for planning and allocation of resources. This is the reason why we attempt to transform the data into synthetic panel data labeled pseudo panel data by the literature. This form of panel data allows capturing both locational heterogeneity and temporal changes in the prevalence of landmine accidents. ${ }^{3}$

Panel data is constructed through pooling the observations from time-series data across different cross-sectional units, such as countries, regions, firms, or households. It allows capturing heterogeneity among the units observed and temporal patterns of their behavior over time. In particular, panel data sets, in addition to estimation of effects of observable variables, have the advantage that they can be used to identify and estimate unobservable unit-specific and time-specific effects. It gives a large number of degrees of freedom and more stable parameter estimates. However, the two dimensions of the data lead to more complex estimation procedures. Baltagi (2008) provides a comprehensive review and discussion of econometric estimation of panel data.

The data in our study is collected by the United Nations Office for Project Services Mine Action Program's (UNOPS MAP) general survey teams covering mine-affected areas in the Kurdistan Region. The data set consists of 12,863 killed/injured observations. It covers the time period of 1970 to 2003 for 26 main districts in the Kurdistan Region. A pseudo panel data is created to be able to specify a multivariate regression model to analyze the outcome of mine accidents. Here, the victims are grouped according to their time-invariant characteristics over time. Pseudo panel data is useful in cases where policy target groups of individuals are distinguished by their common time invariant characteristics, rather than as individuals. Moreover, grouping into cells will homogenize the individual effects so that the average district specific effect is approximately invariant between two periods, and if necessary for estimation purpose, is efficiently removed by within or by first difference transformations of the data (see Deaton, 1985).

The pseudo panel data is created using the repeated cross sections where the outcome is panel data consisting of regions observed over time. Each observation represents average or cohorts of multiple observations for a region in a given year. It is common that one multiplies the average observation with the square root of the cell size to account for different intensities in the size effect. The resulting error component panel data model is:

$$
y_{c t}=\alpha_{0}+\sum_{j=1}^{J} \beta_{j} x_{j c t}+\varepsilon_{c t}, \quad \text { where } \varepsilon_{c t}=\mu_{c}+\lambda_{t}+v_{c t}
$$

where y is outcome of accident for cohort $c$ observed in time period $t, \mathrm{x}_{\mathrm{ct}}$ is a matrix of $J$ explanatory variables, $\beta_{\mathrm{j}}$ is a vector of $J$ unknown parameters to be estimated, $\mu_{\mathrm{c}}$ are unobserved individual effects, $\lambda_{\mathrm{t}}$ are unobserved time effects, and $v_{\mathrm{ct}}$ are random error

${ }^{3}$ For discussion of the properties of pseudo panel data and their advantages and limitations, see Verbeek (1992), Verbeek and Nijman (1992); for their applications, see Heshmati and Kumbhakar (1997). 
terms, and, following the tradition, it is assumed to have a mean zero and a constant variance. This specification allows for the standard within or least square dummy variable estimation of unknown parameters that are consistent and unbiased under the assumption of fixed effects. Since our data uses districts as the unit of observation and it contains all districts, a fixed effects approach is suitable.

\section{The Pseudo Panel Data}

The data was collected mainly by UNOPS MAP through conducting a general impact survey by visiting all mine-affected villages in the Kurdistan Region. The MAP team interviewed the key persons in these villages and the victim's nearest relative or head of the family using a questionnaire form. The data set covers the period 1970-2003 for 26 main districts in the Kurdistan Region. It consists of 12,863 killed/injured individual observations. The data has not been updated by the regional mine action authority since 2003 when the UNOPS MAP's activities were terminated during the coalition force invasion of Iraq. The data contains information about outcome of the accidents in the form of killed/injured and a number of individual and regional socioeconomic characteristics, such as age, gender, occupation, activity at the time of accident, knowledge about the danger, training program, location, and time of accident. In Table 1, we present detailed descriptions and definitions of the variables used in our analysis. The summary statistics of the data used are presented in Table 2 in two parts: one is based on the original repeated cross-sectional data, and the other is based on the constructed pseudo panel data.

\section{Insert Table 1 about here}

In the cross-sectional data case, the victim occurrence time interval is 1929-2008, whereas in the pseudo panel the data is grouped based on time interval 1970-2003 because there were only a few victim records before and after these periods (see Figure 1). The original data contains 12,863 observations, while the pseudo panel data is an unbalanced panel data with 738 observations. The difference is due to the fact that, instead of individuals in the cross-sectional case in the pseudo panel, we use the district of location as the unit of observation. The issue of maintenance of the property of the data retained and truncation of the time period can be checked and showed through comparing the average mean of the key variable across the two data sets.

\section{Insert Figure 1 about here \\ Insert Table 2 about here}

The average age of the victim is 27.5 (27.7) years with 16.4 (10.1) years in dispersion around the mean age. About $82 \%(79.0 \%)$ of the victims were killed in the cross-sectional data case with dispersion of $3.8 \%(2.7 \%)$. The numbers in parenthesis are those of the pseudo panel data. The equality of age and killed rate following an accident indicates that the pseudo panel data construction and use of cell average do not lead to loss of within cohorts' information. It shows that the properties of the parameter estimates are not changing noticeably because of the use of cohort means. We observe that the difference between the mean values of the variables in both scenarios is relatively small whereas the 
rate of dispersion is smaller in the pseudo panel. The pseudo model's fit measured by coefficients of determination or root mean squared errors is much better.

According to the pseudo panel data results, $79 \%$ of the victims are killed when being subjected to landmine accidents, in which only $2 \%$ were children. In total, $17 \%$ were working as Peshmarga soldiers, $33 \%$ as farmers, $15 \%$ as shepherds, and the remaining were unemployed, drivers, or other professionals. For the activity when the accident happened, $31 \%$ of the victims were touching the mine for the purpose of relocating it, $27 \%$ were walking inside the minefield, $26 \%$ were collecting the mine to be destroyed, and the remaining were either fighting, making fires, or engaged in others daily activities. The results show that only $22 \%$ of the victims knew that the area was dangerous, and only $3 \%$ of the victims had received mine awareness information and training programs.

The victim's status (killed $=1$ or injured $=0$ ) is used as the dependent variable. In the crosssectional case, one must use qualitative logit or probit models to estimate the effects of determinants on the probability of getting killed or injured in the event of an accident (see Greene, 2008). The problem here is that we do not have information about non-victims as the statistics cover only landmine victims, which causes a sample selection bias. In the pseudo panel case, the dependent variable is the share of victims killed, which is a continuous variable in the interval 0 and 1 where the level is ignored. Alternatively, one can use the aggregate number of killed and injured as a dependent variable. The aggregate number has the advantage that it accounts for levels and allows for the use of the log-linear functional form, easing direct interpretation of the estimated coefficients. The estimation result should not differ by using the share of killed or the count numbers of killed in accidents, given the same explanatory variables are used in the two model specifications. These two variable definitions allow estimation of the models by using traditional regression models such as pooled, fixed, or random effects models. The model will estimate the effects of determinants on the probability of getting killed.

For explanatory variables, we used individual demographic characteristics, and we were able to distinguish the age and gender of the individual victims. Occupation is specified as: Peshmarga soldiers, child, unemployed, shepherd, farmer, driver, and other occupation. Activity at the time of accident is divided into: walking in the minefield, touching the mine to destroy it, collecting the mines, engaging in conflicts taking place in the minefield, making fire for cooking, and other activities. We also have information about whether the victims knew about the dangers in the area or not, and whether the victims received a mine awareness training program or not. In addition to the above determinants, we have controlled for unobserved district and time of accident effects by using 26 districts and 34 yearly time dummies. As an alternative to the use of yearly time dummies, we used a time trend and its square.

The majority of the victims $(91.2 \%)$ in the data set are male. The average age is 27.6 years. Of the victims $82.2 \%$ were killed and the remaining $17.5 \%$ were injured. Farmers $(38.3 \%)$, children $(24.0 \%)$, Peshmarga soldiers $(13.3 \%)$, and shepherds $(12.9 \%)$ are the main occupation groups of victims. Concerning the nature of the victims' activities at the time of accident, touching mines $(32.3 \%)$, walking in the minefield $(28.8 \%)$, and collecting mines $(28.3 \%)$ are the main activities. Only $24.0 \%$ of the victims were aware of the danger, and 
only $2.5 \%$ had participated in information and awareness programs. These numbers are based on the original data of 12,863 landmine victim cases, which are close to their pseudo panel data counterparts mean values.

In a number of tables and graphs in the appendix, we report aggregate time series of the key variables by different characteristics of the individual victims. Development of the number of victims divided into killed and injured, the two categories' share of the total number of victims, and the share of killed distinguished by gender are reported in Appendix Table A and further illustrated in Figure A1, A2, and A3. The irregular numbers around 1977-1978 and 2000-2003 are very likely attributable to statistical errors and not necessarily to health care effectiveness or changes in the landmines' devastation effects. The variations in percentages of killed across occupation groups and their development over time are reported in Appendix Table B and their number and shares of killed illustrated in Figure B1 and B2. The variations in percentages of killed across different activity groups and their development over time are reported in Appendix Table $\mathrm{C}$, and their number and shares of killed illustrated in Figure $\mathrm{C} 1$ and $\mathrm{C} 2$. In a similar way, the variations in the number and percentages of killed who were aware of the danger and participated in mine awareness programs and their development over time are illustrated in Appendix Figure D1 and D2.

Table D shows the number of killed and injured across different districts. We observe large variations in the size of the population. In general, there is a negative relationship between the population density and frequency of accidents. The number of killed per 1,000 population in the two major cities of Erbil and Suleimaniyah is, relative to other districts, low, 0.27 and 1.12, respectively. The numbers are far below those of Derbandikhan (10.17), Pemjwin (20.72), Choman (20.94), and Sarbazher (50.83). The ratio of killed to injured is large, indicating low access and long distance to professional health care centers within these districts.

\section{The Model and Estimation Procedures}

We have constructed four models to explain variations in the share of killed victims by information obtained on socioeconomic characteristics of the individuals. These models are fixed effects and formulated as follows.

Model 1 is a fixed effects time dummy model where districts and year dummies are included to capture unobserved time-specific and district-specific effects. The variables are average observations in a district for a given year. No adjustment is made for the cell (district) size or frequency of victims for a district in a given year. The frequency of victims varies by district and over time. The overall frequency of accidents or development of the number of victims over the period 1970-2003 is shown in Figure 1.

Model 2 is a fixed effects time dummy model that accounts for district-specific and timespecific effects. The difference with Model 1 is that the variables are adjusted for the frequency of accidents in a district in a given year. The model accounts for size of cell by allowing for its impact on the determinants of the accident rate and the outcome but at a 
decreasing rate because the square root of the number in the cell is used in the multiplication with the variables.

Model 3 and 4 correspond to Model 1 and 2, but the difference is that in these two models, instead of using yearly time dummies to capture unobserved time-specific effects, we include a time trend and its square. This will reduces the number of time-specific effects from 34-1 to only 2, excluding the intercept representing the reference year (1970). Despite its non-linearity in time, it loses power, which comes at the cost of losing year-to-year variations, but on average the two models should provide somewhat similar trends. In our view, the time dummy model should be preferred because the frequency distribution over time (See Figure 1) suggests the time trend is ineffective in capturing the year-to-year variations.

Multicollinearity is the condition where the independent variables are linearly related to each other. A model with high correlation between two or more independent variables is said to have a multicollinearity problem (Wooldridge, 2006). Through specification of our models, we incorporate explanatory variables that are highly correlated with the dependent variable, but we choose explanatory variables that are not correlated with each other to avoid mixing the effects estimated in the form of coefficients. Correlation coefficients between 0 and 0.3 are considered weak, those between 0.3 and 0.7 are moderate, and those between 0.7 and 1.0 are considered high. Therefore, it is desirable that the interpretation of the effects of explanatory variables in the regression results is reliable and not confounded. In general, in textbooks \pm 0.50 is used as the threshold in the evaluation of multicollinearity. However, an acceptable interval of correlations reported by Wheeler and Tiefelsdorf (2005) is somewhat higher, \pm 0.59 .

\section{Insert Table 3 about here}

In all the models under study, correlation coefficients between the independent variables that are reported in Table 3 are less than \pm 0.54 and statistically significant mostly at less than a $1 \%$ level of significance, which indicates that multicolinearity is not a serious problem in this case. Some of the explanatory variables are positively correlated, while others are negatively correlated with all explanatory variables, including age, gender (male), occupation, activity, knowledge, and trend. The degree varies in the interval -0.53 till +0.10 . The highest negative value is age, while the highest positive occupation is farmer in relation to the dependent variable. Some of the independent variables are also positively correlated, while others are negatively correlated. As mentioned previously, the degree of correlation here is lower than the threshold for the serious degree of collinearity. The highest correlation coefficient is -0.54 , which is attributed to unemployed-male combination. A few other negative correlations are child-age $(-0.36)$, walk-touch $(-0.41)$, collect-touch (-.041), and collect-walk (-0.37) related to the nature of activities.

Estimation results are reported in Table 4. As mentioned previously, four models are estimated in which they differ according to whether in the construction of the pseudo panel one accounts for the frequency of accidents or uses simple averages by districts, and whether the time-specific effects are captured by yearly time dummies or a time trend and its square. 


\section{Insert Table 4 about here}

The F-test is a statistical test used to evaluate the null hypothesis that all slope regression coefficients are equal to zero versus the alternative that the intercept is not zero. A significant F-test indicates that the observed R-squared is reliable and is not a spurious result of oddities in the data set. Thus, the F-test determines whether the proposed relationship is statistically reliable. The F-tests in the four estimated models are all statistically significant at less than a $1 \%$ level of significance, suggesting that the model specification is adequate. The Bayesian Information Criterion (BIC) and Variance Inflation Factors (VIF) also suggest the models are not being over-fitted and specified correctly. The standard errors are robust standard errors corrected for heteroscedasticity.

By looking at the adjusted R-square for Model 1 (0.672) and Model 3 (0.539), where the variables are not adjusted for the cell size, this shows that only $67.2 \%$ and $53.9 \%$, respectively, of the variations in the dependent variable killed can be explained. By looking at the estimated coefficients in Model 4, where the fixed effects of location and time trend are considered and the variables are adjusted for the cell size, we notice that all the variables are statistically significant at a $1 \%$ level of significance. The adjusted Rsquare is 0.941 , implying that $94.1 \%$ of the killed data is well explained by this model. The R-square in the model, using yearly time dummies and accounting for frequency of the killed at the district level (Model 2), is 0.947 . Thus, the explanatory power of Model 2 is highest among the four estimated models.

In this case we cannot select our preferred model simply based on the coefficient of determination. Chow test was conducted to compare the time dummy vs. time trend models, Model 2 vs. Model 4. The test result $(\mathrm{F}=1.373)$ suggests that the preferred model is Model 4, which accounts for frequency of accidents in a given district and use of a time trend to capture the unobservable time-specific effect. In comparing the time trend and time dummy models, we notice that the remaining parameters' significance level, sign, and size seem to be robust and not affected by the specification of time-specific effects. Furthermore, the two models are not exactly nested and, as such, not testable using Chow test. Based on these two facts, we should base our analysis on Model 4. However, we prefer the time dummy because the two models are not exactly nested, and therefore Model 2 is considered the preferred model specification.

\section{Interpretation of the Results}

The basic model estimated by ignoring district and time effects (not reported here) produces R-square of 0.467 . Chow tests of the four reported models vs. the basic model show that the former models are preferred. The sole introduction of year dummy variables in Model 1 without adjusting for the cell size compared with Model 2 (adjusted) shows that the percentage of explained variations in the dependent variable rise from $67.2 \%$ to $94.7 \%$. This has another implication, namely, it confirms that it is important to account for the frequency of the accident rate among the districts. 
The result shows that the male effect is statistically significant in both Model 2 and 4, suggesting that males are more often subject to landmine accidents than their female counterparts due to the nature of their work. When adding the square of age to account for non-linear relationship between accident rate and age, we find age to be statistically significant in both Model 2 and 4 at less than a 1\% level of significance. The squared term coefficient is insignificant, suggesting a linear relationship between accident rate and age of the victims. A higher age is associated with higher probability of being killed. However, the effect of age varies when district effects are controlled.

Estimation results based on Model 2 suggest that children compared with Peshmarga soldiers as a reference group are more prone to landmine accident. The opposite is observed in Model 3. Similarly, the unemployed, shepherds, farmers, drivers, and other professions face landmine accidents more often than Peshmarga soldiers. The coefficient of the activity of touching mines is negative and significant, suggesting that walking is the main activity leading to fatalities. The remaining activities are not statistically different from the reference variable of walking. Unlike in the case of Husum et al. (2002), the data does not allow for post-accident treatment, rehabilitation, and evaluation of chronic pain in landmine accident survivors.

Only in Model 3 do we notice that information about danger of landmine reduces the rate of accidents. Contrary to our expectations, participation in landmine training and awareness programs does not reduce the rate of accidents. This might be explained by the low frequency and/or ineffectiveness of such programs. Low rate of literacy in the rural areas might be another factor explaining the low training and awareness program effect.

District-specific effects, which are constant over time, are captured in the form of fixed effects. Akre is used as the reference district. Compared with Akre, the coefficient of five districts in Model 2 and six districts in Model 4 are statistically different from Akre. The negative sign suggests a lower accident rate than Akre. DashtiHawler, Dukan, Peshdar, and Ranya have a lower accident rate perhaps due to low landmine concentration in these areas. Only nine of the yearly time dummy variables are found to be statistically different than that of the reference year 1970. The rate is lower in all nine years compared with 1970. In regards to the alternative specification with time trend and its square, we notice that in Model 3 and 4 both coefficients are negative and statistically significant. The signs suggest that the accident rate is declining at an increasing rate, which is contrary to the insignificant training program effects.

\section{Socioeconomic, Psychological, and Health Impacts}

The socioeconomic impact of landmines and UXO extends across multiple areas, such as access to public areas, salvaging metal from mines and UXO, accessing land for agriculture, and repairing existing infrastructures. The impact of landmines on socioeconomic aspects can be either direct or indirect. The indirect impacts of landmines include malnutrition/starvation and the spread of infectious diseases because of the inability to repair water purification systems and to provide public health services in areas isolated by mines and UXO. 
Our data does not fully allow for assessment of social, psychological, and economic impacts of landmine accidents. The literature in this area is not developed, but there are examples of studies covering these important aspects. For instance, Anderson et al. (1995) investigated the effects of landmines on the health and social conditions of communities in four countries (Afghanistan, Bosnia, Cambodia, and Mozambique). The focus was on the effects of landmines on food security, residence, livestock, land use, extent of injuries, as well as the physical, psychological, social, and economic costs of injuries. Landmines were found to undermine the food security and economy of the affected countries. Kakar et al. (1996) also found landmines to constitute a major public health problem in the world, suggesting its production ban.

In order to know the extent of the impact of landmine and UXO on social, health, and economic sectors, it is worth mentioning that planting one mine costs US\$3-15, while the process of removing it, ignoring the risk, costs US\$100-350. According to UN estimates, the cost of treating an injured person as a result of the explosion of a mine is more than three times the cost of treating a person injured by other means ${ }^{4}$. Medical reports indicate that a mine victim, if not killed, needs at least three surgical operations in addition to further medical supplies. The minimum cost of treating a mine victim is US\$6,000; each prosthetic limb costs US $\$ 3,000-5,000$, and every prosthetic limb needs to be replaced for the victim every six months. Hence, the effects of landmines go far beyond killing, injuring, and disabling humans to affecting the nation's economy and individuals' wellbeing (Coupland, 1996). In recent years, the sharing of oil revenues between regional and central governments in Iraq in proportion to the share of population allowed the building up of health care capacity (Al-Bazzaz, 2010) and the conducting of landmine treatment and rehabilitation (Shabila et al., 2010). However, due to the public and not-for-profit nature of these services, they are underinvested and underdeveloped.

The economic sector that is mostly harmed by the presence of landmines in the Kurdistan Region is the agriculture sector. The presence and threat of landmines often disrupt agricultural development and consequently the health and well-being of the rural population. There are several effects from landmines on agriculture throughout. They affect the amount of arable land for cultivation. Most of the fertile lands are mined, which in turn affects the supply of food and limits employment opportunities. The mined grazing lands limit animal husbandry activities, which are traditionally of significant importance for food supply. These landmines have not only stalled the agriculture sector but have also killed large numbers of livestock, the main source of livelihood in the rural areas. Landmines not only obstruct the development of agriculture, they also hinder economic development in general as a result of reduced investment. In line with Harris (2000) and critical commentary by Paterson (2001), one should conduct a cost-benefit analysis of landmine clearance of agricultural land to justify resource allocation for clearance activities, treatment, and rehabilitation. However, many of the positive social effects of such investments are not possible to measure quantitatively and monetarily.

\footnotetext{
${ }^{4}$ http://www.un.org/cyberschoolbus/banmines/units/unit1c.asp, Landmine-Related Injuries (1993-1996), Morbidity and Mortality Weekly Report 1997, 46, 724-726.
} 
In addition to the physical impact and the socioeconomic consequences of landmine injuries, they have severe emotional and psychological impact on the victim's family. The emotional status of landmine victims is important because disabled individuals often turn to alcohol and acquire aggressive behaviors, which result in serious public health and social problems. Thus, the mere threat of the existence of landmines, let alone their actual presence, disrupts everyday activities, such as fetching safe water and cultivating fields for food production. It also deters public health campaigns and dramatically alters the social and economic state of the injured and their families, ultimately affecting the structure and well-being of entire societies. Accounting for all of these negative effects and externalities, it is to be admitted that these effects were expected by the central government's armed forces who placed the mines in the first place with the aim to depopulate the region and to effectively destroy the livelihood of the citizens who were demanding their constitutional and international human rights.

Landmines continue to maim and kill. These weapons also cause mental health consequences for victims and their families. In addition, small arms and landmines cause a substantial burden on the health sector as well as the economic condition of the families of the victims. The economic costs associated with injuries from small arms and landmines are estimated to be in the billions of dollars each year. ${ }^{5}$. These consume a large share of public and private budgets, reducing the states' and households' potential for development and prosperity.

\section{Summary, Conclusion and Policy Recommendations}

Landmine and UXO are aimed to be used in war or conflicts between countries for defense and security reason. However, their use has frequently been abused by some national governments against rebelling minorities with the purpose of depopulation of certain regions in order to change the demography in an attempt to monopolize natural resources utilization. Thus, natural resources are a double curse for minorities.

This study analyzed data of victims caused by mines and UXOs in the Kurdistan Region of Iraq. The data is yearly cross sections collected from the late 1960s until 2003. In addition to descriptive analysis, we use regression analysis to identify determinants of the probability of getting killed by a landmine and to estimate the individual determinants' impacts. The individuals are observed when they are subjected to landmine accidents. In order to account for the dynamic aspect of the process and heterogeneity by location, we created pseudo panel data where each of the districts is observed over time for the entire period. This allows for analysis of both heterogeneity and dynamics across locations and over time, as well as to control for unobserved location and time effects. In our view, the result based on the pseudo panel data is more useful in monitoring, planning, and resource allocation.

\footnotetext{
${ }^{5} \mathrm{http} / /$ www.picosearch.com/cgi-bin/ts.pl?index=159730\&calln=6\&lastq=\&sortsel=rel\&psel=jma\&opt= ANY\&query=health\%20impact
} 
Empirical results show that males are more often subjected to landmine accidents than their female counterparts, which is attributed to the nature of their activities. There is a negative age effect, suggesting younger people are less exposed to the risk of accidents. The probability of accident is lower for children, unemployed individuals, shepherds, farmers, and drivers compared to Peshmarga soldiers. Walking is the type of activity that leads to a higher rate of accidents compared with touching of mines and other daily activities. Awareness of landmine danger reduces the probability of accident, but no significant reduction is observed from participation in training programs.

Concerning the unobserved time and district effects, we noted that in some districts and years the accident rate is higher than in 1970 and in Akre, which serve as reference year and district, respectively. A major part of the decline in the rate of accidents is attributed to urbanization and migration from agriculture to service and industry sectors. Despite these major changes, the population is highly exposed to disproportionate danger of landmines harming the economy and social life, and landmines cause enormous psychological suffering and pain for the entire population.

The Kurdistan Regional Government is urged to allocate a fixed share of its annual budget that is raised from oil and gas revenue sharing to landmine awareness and clearance, health care capacity and quality, and rehabilitation programs. This will make the region independent of foreign NGOs, which might take longer than expected to clear the area due to other priorities around the world. Planning and management of mine action, health care, and rehabilitation in the Kurdistan Region should be strictly in the hands of local people. Currently, the stalled mine action group's activity is in the hands of the central government, sections of which in the past actively participated in mining the region. As such, a centrally nominated and financed authority is certainly not trustworthy to lead the clearing actions and related health and rehabilitation activities. Judging from the recent years of high public revenues, there is no shortage of funds to reactivate the landmine action group in the region in order to cope with this hazardous factor that harms the general population.

A research institute should be established to conduct research on landmines and collecting statistics. Such an institute should play a major role in coordination of research related to different aspects of landmines, such as information, prevention, training and rehabilitation, labor market and pension. In addition, it should enable the gathering of evidence on crimes committed and encourage and support the regional governments in following up on the landmine issue in matters of prevention, reducing impacts, victim compensation, and punishing the criminals for the crimes they committed. 


\section{References}

Al-Bazzaz, P.H. (2010), "Kidney Transplantation in Erbil, Iraq: A Single-center Experience", Saudi Journal of Kidney Diseases and Transplantation, 21(2), 359-62.

Andersson, N., da Sousa, C.P. and Paredes, S. (1995), "Social Costs of Landmines in Four Countries: Afghanistan, Bosnia, Cambodia, and Mozambique", British Medical Journal, 311, 718-721.

Ascherio, A., Biellik, R., Epstein, A.,Snetro, G., Gloyd, S., Ayotte, B. and Epstein, P.R. (1995), "Deaths and Injuries Caused by Landmines in Mozambique", Lancet, 346, 721-725.

Baltagi, B.H. (2008), "Econometric Analysis of Panel Data", Fourth Edition, John Wiley and Sons, Ltd.

Benedinelli, C. (2009), "Effects of Landmines and Unexploded Ordnance on the Pediatric Population and Comparison with Adults in Rural Cambodia", World Journal of Surgery, 33(5), 1070-1074.

Berthiaume, A., (2003), "Gender and Landmines", Resource prepared for Youth Mine Action Ambassador Program, Ottawa, Canada: International Campaign to Ban Landmines.

Bottomly, R. (2003), "Crossing the Divide: Landmines, Villagers and Organisations", Oslo, Norway: International Peace Research Institute.

Champion, H.J.R., Sacco, W.J. and Copes, W.S. (1989), "A Revision of the Trauma Score",Journal of Trauma, 29, 623-629.

Coupland, R.M. (1996), "The Effect of Weapons: Defining Superfluous Injury and Unnecessary Suffering”, A1 Medicine and Global Survival, 3, 1-7.

Deaton, A. (1985), "Panel Data from Time Series of Cross Sections", Journal of Econometrics, 30, 109-126.

Greene, W. (2008), "Econometric Analysis", Prentice Hall, 6th Edition.

Harris, G. (2000), "The Economics of Landmine Clearance: Case Study of Cambodia", Journal of International Development, 12(2), 219-225.

Heshmati, A. andKumbhakar,S.C. (1997), "Estimation of Technical Efficiency in Swedish Crop Farms: A Pseudo Panel Data Approach", Journal of Agricultural Economics, 48(1), 22-37.

Husum, H., Resell, K., Vorren, G., Van Heng, Y., Murad, M., Gilbert, M. and Wisborg, T. (2002), "Chronic Pain in Landmine Accident Survivors in Cambodia and Kurdistan", Social Science and Medicine, 55, 1813-1816.

Jahanlu, H.R., Husum, H. and Wisborg, T. (2002), "PrehospitalMortality in Landmine Accidents in Iran",Prehospital Disaster Medicine, 17(2), 107-109.

Kakar, F., Bassani, F., Romer, C.J. and Gunn, S.W.A. (1996), "The Consequence of Landmines on Public Health",Prehospital Disaster Medicine, 11, 2-10.

Krug, E.G., Ikeda, R.M., Qualls, M.L., Anderson, M.A., Rosenberg, M.L. andJackson, R.J.(1998), "Preventing Landmine-Related Injury and Disability: A Public Health Perspective", Journal of the American Medical Association, 280, 465-570.

Newman, R.D. and Mercer, M.A. (2000), "Environmental Health Consequences of Landmines", International Journal of Occupational Environment and Health, 6(3), 243-248. 
Paterson T. (2001), "Commentary on the Economics of Landmine Clearance: Case Study of Cambodia", Journal of International Development, 13, 629-634.

Quesada, J. (1998), "Suffering Child: An Embodiment of War and its Aftermath in PostSandinista Nicaragua",Medical Anthropology Quarterly, 12, 51-73.

Roberts, S. and Williams, J. (1995), "After the Guns Fall Silent. The Enduring Legacy of Landmines", Washington, DC: Vietnam Veterans of America Foundation.

Shabila, N.P., Taha, H.I.and Al-Hadithi, T.S. (2010), "Landmine Injuries at the Emergency Management Center in Erbil, Iraq", Conflict and Health, 4, 15, 1-6.

Verbeek, M. (1992), "Pseudo Panel Data", in Maytas L. and Sevestre P. (eds), The Econometrics of Panel Data, 303-314, Kluwer Academic, Amsterdam.

Verbeek, M.,Nijman,T. (1992), "Can Cohort Data be Treated as Genuine Panel Data?", Empirical Economics, 17, 9-23.

Wheeler, D. andTiefelsdorf, M. (2005), "Multicollinearity and Correlation among Local Regression Coefficients in Geographically Weighted Regression", Journal of Geographic System, 7(3), 161-187.

Wooldridge, J.M. (2006), "Introductory Econometrics", $4^{\text {th }}$ Edition, Michigan State University. 
Figure 1: Prevalence of landmine accidents over time in the Kurdistan Region of Iraq.

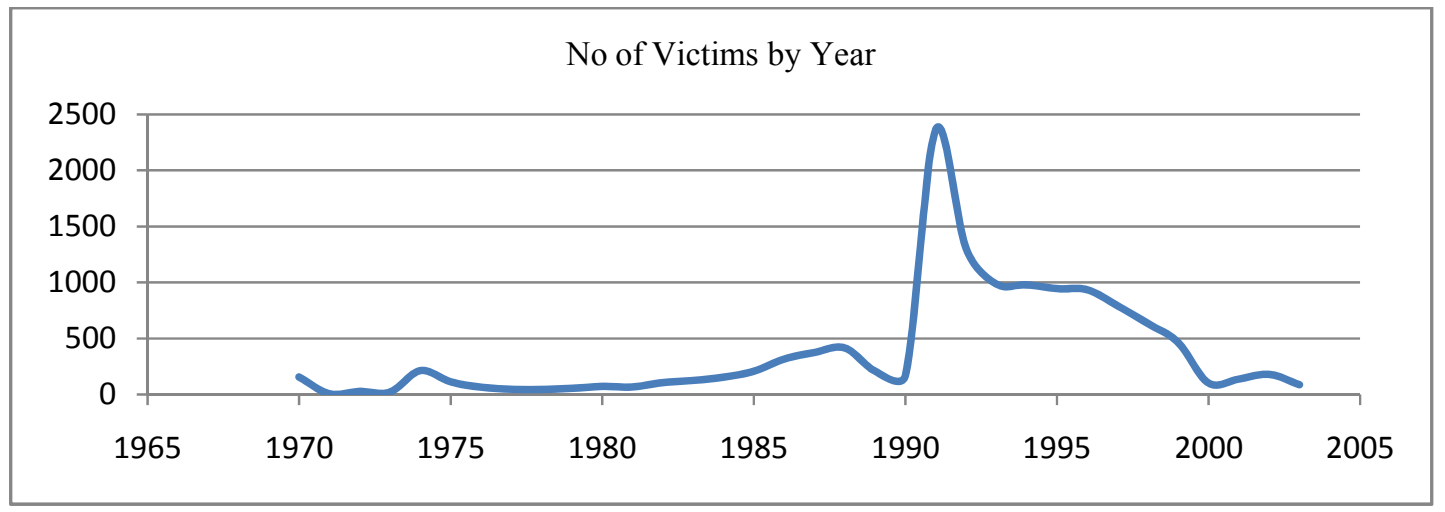

Table 1: Description of Variables

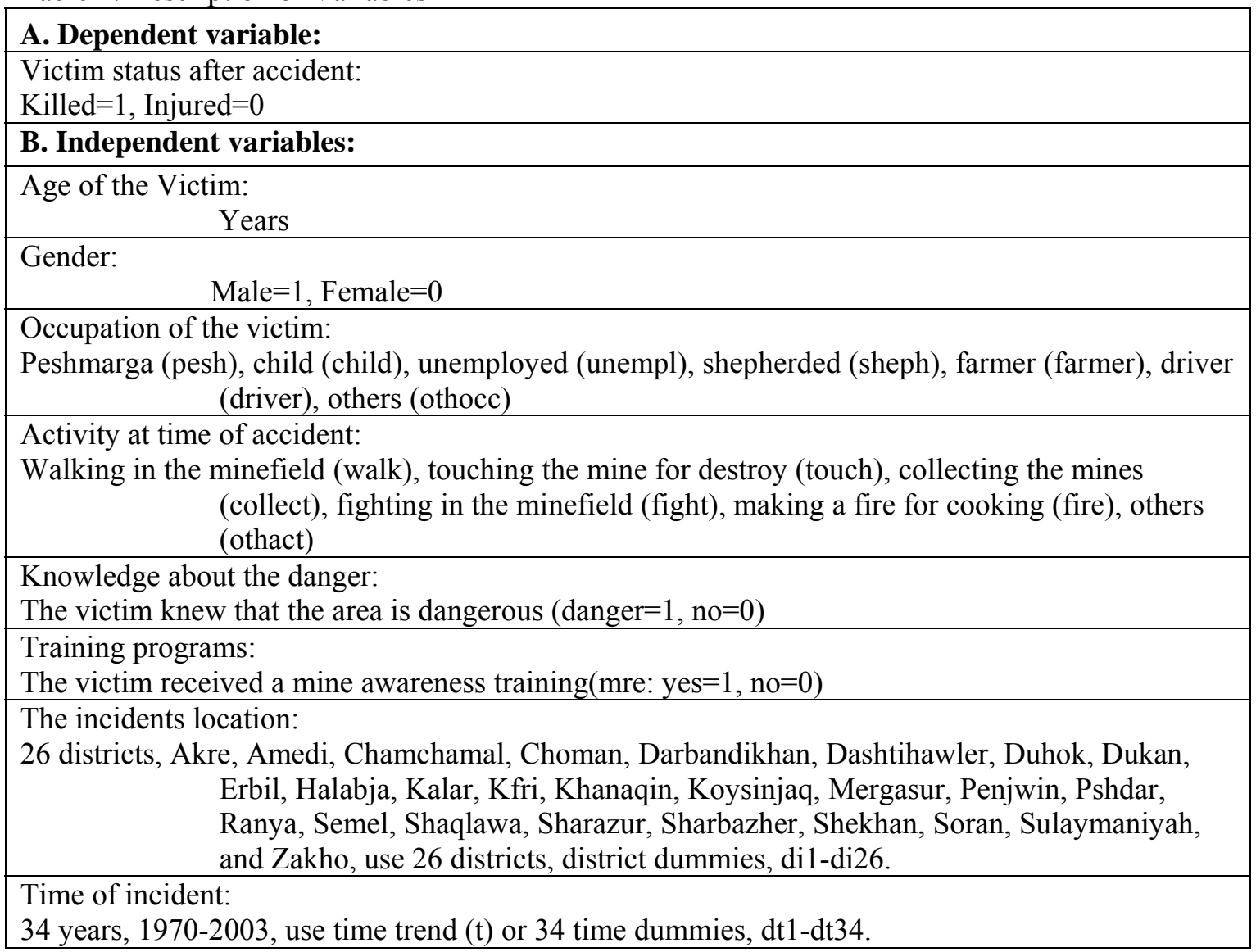


Table 2: Summary Statistics for the variables used

\begin{tabular}{|c|c|c|c|c|c|c|c|c|c|c|}
\hline & \multicolumn{5}{|c|}{$\begin{array}{l}\text { Repeated cross sectional survey data, } \\
12,863 \text { observations }\end{array}$} & \multicolumn{5}{|c|}{$\begin{array}{l}\text { Pseudo panel data-not accounted for cell size, } \\
738 \text { observations }\end{array}$} \\
\hline Variable & Mean & StdDev & Min. & Max. & t-value & Mean & StdDev & Min. & Max. & $\mathrm{t}$-value \\
\hline male & 0.912 & 0.283 & 0 & 1 & 365.8 & 0.927 & 0.135 & 0 & 1 & 187.35 \\
\hline female & 0.088 & 0.283 & 0 & 1 & 35.19 & 0.073 & 0.135 & 0 & 1 & 14.66 \\
\hline age & 27.578 & 16.406 & 1 & 100 & 190.74 & 27.733 & 10.164 & 3.50 & 77.00 & 74.13 \\
\hline killed & 0.822 & 0.383 & 0 & 1 & 243.81 & 0.798 & 0.278 & 0 & 1 & 78.11 \\
\hline injured & 0.178 & 0.383 & 0 & 1 & 52.80 & 0.202 & 0.278 & 0 & 1 & 19.72 \\
\hline pesh & 0.133 & 0.340 & 0 & 1 & 44.46 & 0.178 & 0.242 & 0 & 1 & 19.94 \\
\hline child & 0.240 & 0.427 & 0 & 1 & 63.71 & 0.215 & 0.250 & 0 & 1 & 23.35 \\
\hline unempl & 0.076 & 0.266 & 0 & 1 & 32.64 & 0.065 & 0.128 & 0 & 1 & 13.73 \\
\hline sheph & 0.129 & 0.335 & 0 & 1 & 43.65 & 0.157 & 0.233 & 0 & 1 & 18.39 \\
\hline farmer & 0.383 & 0.486 & 0 & 1 & 89.47 & 0.338 & 0.278 & 0 & 1 & 32.99 \\
\hline driver & 0.037 & 0.189 & 0 & 1 & 22.26 & 0.044 & 0.121 & 0 & 1 & 9.96 \\
\hline othocc & 0.001 & 0.037 & 0 & 1 & 4.25 & 0.003 & 0.035 & 0 & 0.67 & 2.56 \\
\hline walk & 0.288 & 0.453 & 0 & 1 & 72.15 & 0.270 & 0.264 & 0 & 1 & 27.73 \\
\hline touch & 0.323 & 0.468 & 0 & 1 & 78.38 & 0.318 & 0.291 & 0 & 1 & 29.68 \\
\hline collect & 0.263 & 0.440 & 0 & 1 & 67.74 & 0.265 & 0.280 & 0 & 1 & 25.70 \\
\hline fight & 0.023 & 0.151 & 0 & 1 & 17.50 & 0.037 & 0.121 & 0 & 1 & 8.37 \\
\hline fire & 0.018 & 0.134 & 0 & 1 & 15.54 & 0.016 & 0.070 & 0 & 1 & 6.14 \\
\hline othact & 0.085 & 0.278 & 0 & 1 & 34.51 & 0.094 & 0.159 & 0 & 1 & 16.12 \\
\hline danger & 0.240 & 0.427 & 0 & 1 & 63.82 & 0.228 & 0.273 & 0 & 1 & 22.72 \\
\hline mre & 0.025 & 0.155 & 0 & 1 & 18.09 & 0.035 & 0.132 & 0 & 1 & 7.30 \\
\hline trnd & - & - & - & - & - & 18.725 & 9.270 & 1.00 & 34.00 & 54.87 \\
\hline
\end{tabular}

Note: $t$-value indicate probability of variable being different than zero. 
Table 3: Pearson Correlation Coefficients (738 Observations)

\begin{tabular}{|c|c|c|c|c|c|c|c|c|c|c|c|c|c|c|c|c|c|c|c|}
\hline & killed & male & age & pesh & child & unempl & sheph & farmer & driver & othocc & walk & touch & collect & fight & fire & othact & danger & mre & trnd \\
\hline killed & 1 & 0.013 & -0.532 & -0.068 & -0.091 & 0.091 & 0.013 & 0.103 & -0.006 & -0.094 & 0.047 & -0.036 & -0.040 & -0.029 & -0.010 & 0.083 & -0.151 & -0.176 & -0.110 \\
\hline male & -0.013 & 1 & -0.024 & 0.133 & -0.077 & -0.537 & 0.169 & 0.028 & 0.064 & 0.023 & -0.017 & -0.010 & 0.085 & 0.012 & -0.142 & -0.051 & 0.023 & 0.070 & 0.056 \\
\hline age & -0.532 & -0.024 & 1 & 0.154 & -0.362 & 0.012 & -0.090 & 0.202 & 0.127 & 0.037 & 0.150 & -0.175 & -0.004 & 0.098 & 0.017 & -0.004 & -0.058 & 0.004 & -0.050 \\
\hline pesh & -0.068 & 0.133 & 0.154 & 1 & -0.269 & -0.133 & -0.242 & -0.306 & -0.116 & -0.067 & 0.251 & -0.240 & -0.178 & 0.298 & -0.061 & 0.137 & -0.193 & -0.039 & 0.001 \\
\hline child & -0.091 & -0.077 & -0.362 & -0.269 & 1 & -0.083 & -0.222 & -0.388 & -0.112 & -0.037 & -0.112 & 0.306 & -0.155 & -0.149 & 0.037 & -0.005 & 0.088 & 0.032 & 0.057 \\
\hline unempl & 0.091 & -0.537 & 0.012 & -0.133 & -0.083 & 1 & -0.134 & -0.130 & -0.058 & -0.017 & 0.068 & -0.030 & -0.050 & -0.051 & 0.141 & 0.008 & -0.001 & -0.073 & 0.027 \\
\hline sheph & 0.013 & 0.169 & -0.090 & -0.242 & -0.222 & -0.134 & 1 & -0.322 & -0.094 & -0.008 & -0.227 & 0.032 & 0.306 & -0.130 & -0.041 & -0.102 & 0.110 & 0.020 & -0.014 \\
\hline farmer & 0.103 & 0.028 & 0.202 & -0.306 & -0.388 & -0.130 & -0.322 & 1 & -0.125 & -0.009 & 0.053 & -0.063 & 0.062 & -0.064 & 0.002 & -0.034 & -0.051 & -0.058 & -0.073 \\
\hline driver & -0.006 & 0.064 & 0.127 & -0.116 & -0.112 & -0.058 & -0.094 & -0.125 & 1 & -0.025 & -0.006 & -0.028 & -0.026 & 0.169 & -0.029 & -0.009 & 0.065 & 0.141 & 0.023 \\
\hline othocc & -0.094 & 0.023 & 0.037 & -0.067 & -0.037 & -0.017 & -0.008 & -0.009 & -0.025 & 1 & -0.070 & -0.027 & 0.090 & -0.029 & -0.003 & 0.032 & 0.156 & 0.150 & 0.074 \\
\hline walk & 047 & -0.017 & 0.150 & 0.251 & -0.112 & 0.068 & -0.227 & 0.053 & -0.006 & -0.070 & 1 & -0.414 & -0.372 & -0.101 & -0.089 & -0.133 & -0.332 & -0.143 & -0.178 \\
\hline touch & -0.036 & -0.010 & -0.175 & -0.240 & 0.306 & -0.030 & 0.032 & -0.063 & -0.028 & -0.027 & -0.414 & 1 & -0.440 & -0.187 & -0.066 & -0.199 & 0.335 & 0.029 & -0.032 \\
\hline collect & -0.040 & 0.085 & -0.004 & -0.178 & -0.155 & -0.050 & 0.306 & 0.062 & -0.026 & 0.090 & -0.372 & -0.440 & 1 & -0.117 & -0.054 & -0.221 & 0.014 & 0.129 & 0.163 \\
\hline fight & -0.029 & 0.012 & 0.098 & 0.298 & -0.149 & -0.051 & -0.130 & -0.064 & 0.169 & -0.029 & -0.101 & -0.187 & -0.117 & & -0.056 & -0.017 & -0.104 & -0.019 & 0.021 \\
\hline fire & -0.010 & -0.142 & 0.017 & -0.061 & 0.037 & 0.141 & -0.041 & 0.002 & -0.029 & -0.003 & -0.089 & -0.066 & -0.054 & -0.056 & 1 & -0.030 & 0.026 & 0.065 & 0.077 \\
\hline othact & 083 & -0.051 & -0.004 & 0.137 & -0.005 & 0.008 & -0.102 & -0.034 & -0.009 & 0.032 & -0.133 & -0.199 & -0.221 & -0.017 & -0.030 & 1 & -0.020 & -0.057 & 0.018 \\
\hline danger & -0.151 & 0.023 & -0.058 & -0.193 & 0.088 & -0.001 & 0.110 & -0.051 & 0.065 & 0.156 & -0.332 & 0.335 & 0.014 & -0.104 & 0.026 & -0.020 & 1 & 0.268 & 0.245 \\
\hline mre & -0.176 & 0.070 & 0.004 & -0.039 & 0.032 & -0.073 & 0.020 & -0.058 & 0.141 & 0.150 & -0.143 & 0.029 & 0.129 & -0.019 & 0.065 & -0.057 & 0.268 & 1 & 0.323 \\
\hline trnd & -0.110 & 0.056 & -0.050 & 0.001 & 0.057 & 0.027 & -0.014 & -0.073 & 0.023 & 0.074 & -0.178 & -0.032 & 0.163 & 0.021 & 0.077 & 0.018 & 0.245 & 0.323 & 1 \\
\hline
\end{tabular}


Table 4: Fixed effects estimation results, $\mathrm{n}=738$ obs

\begin{tabular}{|c|c|c|c|c|c|c|c|c|}
\hline & \multicolumn{2}{|c|}{$\begin{array}{l}\text { Model 1: fixed effects, } \\
\text { time dummy, no cell } \\
\text { size adjustment }\end{array}$} & \multicolumn{2}{|c|}{$\begin{array}{l}\text { Model 2: fixed effects } \\
\text { time dummy, with } \\
\text { adjustment for cell } \\
\text { size }\end{array}$} & \multicolumn{2}{|c|}{$\begin{array}{l}\text { Model 3: fixed effects, } \\
\text { time trend, no cell size } \\
\text { adjustment }\end{array}$} & \multicolumn{2}{|c|}{$\begin{array}{l}\text { Model 4: fixed effects } \\
\text { time trend, with } \\
\text { adjustment for cell } \\
\text { size }\end{array}$} \\
\hline F-test & \multicolumn{2}{|c|}{$21.42 * * *$} & \multicolumn{2}{|c|}{$181.35^{* * *}$} & \multicolumn{2}{|c|}{$21.10 * * *$} & \multicolumn{2}{|c|}{$274.47 * * *$} \\
\hline Adj $R^{2}$ & \multicolumn{2}{|c|}{0.6721} & \multicolumn{2}{|c|}{0.9477} & \multicolumn{2}{|c|}{0.5398} & \multicolumn{2}{|c|}{0.9410} \\
\hline RMSE & \multicolumn{2}{|c|}{0.1590} & \multicolumn{2}{|c|}{0.5184} & \multicolumn{2}{|c|}{0.1884} & \multicolumn{2}{|c|}{0.5503} \\
\hline Variable & Coefficient & Std Err1 & Coefficient & Std Err1 & Coefficient & Std Err1 & Coefficient & Std Err1 \\
\hline Intercept & $1.0861 * * *$ & 0.0951 & $0.2930 * *$ & 0.1239 & $1.1724 * * *$ & 0.1074 & 0.0379 & 0.1158 \\
\hline male & 0.0480 & 0.0604 & $0.9188 * * *$ & 0.0561 & -0.0114 & 0.0691 & $0.9725 * * *$ & 0.0611 \\
\hline age & -0.0047 & 0.0033 & $-0.0134 * * *$ & 0.0016 & $-0.0092 * * *$ & 0.0039 & $-0.0137 * * *$ & 0.0016 \\
\hline $\mathrm{age}^{2}$ & $-1.47 \mathrm{E}-4 * * *$ & $5.08 \mathrm{E}-5$ & $1.82 \mathrm{E}-6$ & 3.37E-6 & $-1.04 \mathrm{E}-4^{*}$ & $6.13 \mathrm{E}-5$ & $5.19 \mathrm{E}-8$ & $3.08 \mathrm{E}-6$ \\
\hline child & $-0.1422 * * *$ & 0.0513 & $0.1312 * *$ & 0.0625 & $-0.1937 * * *$ & 0.0525 & 0.0955 & 0.0650 \\
\hline unempl & $0.1314^{* *}$ & 0.0694 & $1.0865 * * *$ & 0.0894 & $0.1284 *$ & 0.0767 & $1.0987 * * *$ & 0.0910 \\
\hline sheph & -0.0097 & 0.0540 & $0.2824 * * *$ & 0.0755 & 0.0127 & 0.0644 & $0.3359 * * *$ & 0.0822 \\
\hline farmer & $0.1324 * * *$ & 0.0425 & $0.5137 * * *$ & 0.0574 & $0.1113 * * *$ & 0.0462 & $0.5155^{* * *}$ & 0.0604 \\
\hline driver & $0.1522 * * *$ & 0.0578 & $0.4370 * * *$ & 0.1028 & $0.1425^{* *}$ & 0.0749 & $0.3803 * * *$ & 0.1226 \\
\hline othocc & $0.3590 * *$ & 0.1709 & $0.4566^{* *}$ & 0.2115 & -0.1989 & 0.2263 & -0.2222 & 0.2268 \\
\hline touch & -0.0475 & 0.0411 & $-0.1011 * *$ & 0.0490 & 0.0276 & 0.0478 & -0.0433 & 0.0538 \\
\hline collect & 0.0651 & 0.0409 & -0.0524 & 0.0567 & -0.0548 & 0.0472 & $-0.1036^{*}$ & 0.0623 \\
\hline fight & -0.0993 & 0.0720 & 0.1091 & 0.1180 & -0.0945 & 0.0748 & 0.1349 & 0.1327 \\
\hline fire & 0.0469 & 01081 & 0.0230 & 0.1157 & 0.1122 & 0.1443 & 0.1535 & 0.1357 \\
\hline othact & 0.0338 & 0.0497 & 0.0978 & 0.0680 & $0.0872 *$ & 0.0514 & $0.1472 * *$ & 0.0704 \\
\hline danger & 0.0234 & 0.0389 & 0.0127 & 0.0435 & $-0.1319^{* * *}$ & 0.0506 & -0.0471 & 0.0476 \\
\hline mre & -0.0273 & 0.0926 & -0.0426 & 0.1008 & -0.1835 & 0.1328 & -0.1006 & 0.1173 \\
\hline di2 (distr.) & -0.0043 & 0.0453 & 0.0620 & 0.1327 & 0.0141 & 0.0563 & $0.0155^{* *}$ & 0.1344 \\
\hline di3 & 0.0660 & 0.0444 & 0.1419 & 0.1349 & 0.0448 & 0.0556 & 0.0656 & 0.1572 \\
\hline $\mathrm{di} 4$ & -0.0495 & 0.0493 & 0.0379 & 0.1547 & -0.0236 & 0.0563 & -0.0118 & 0.1563 \\
\hline di5 & 0.0355 & 0.0437 & 0.0307 & 0.1195 & 0.0585 & 0.0548 & 0.0036 & 0.1187 \\
\hline di6 & $-0.2429 * * *$ & 0.0575 & $-0.5298 * * *$ & 0.1553 & $-0.2561 * * *$ & 0.0677 & $-0.5967 * * *$ & 0.1616 \\
\hline di7 & -0.0753 & 0.0536 & -0.1158 & 0.1368 & -0.0447 & 0.0620 & -0.1191 & 0.1480 \\
\hline di8 & $-0.1931 * * *$ & 0.0537 & $-0.6327 * * *$ & 0.1697 & $-0.1463 * *$ & 0.0627 & $-0.6463 * * *$ & 0.1569 \\
\hline di9 & $-0.0955^{* *}$ & 0.0537 & -0.1248 & 0.1477 & $-0.1158 * *$ & 0.0610 & -0.1962 & 0.1611 \\
\hline di10 & 0.0583 & 0.0506 & 0.1875 & 0.1450 & 0.0858 & 0.0562 & 0.1456 & 0.1447 \\
\hline di11 & 0.0507 & 0.0485 & 0.1119 & 0.1357 & 0.0697 & 0.0624 & 0.0772 & 0.1333 \\
\hline di12 & $0.0769^{*}$ & 0.0449 & 0.1148 & 0.1594 & 0.0350 & 0.0690 & 0.0706 & 0.1887 \\
\hline di13 & $0.1021^{*}$ & 0.0608 & 0.0760 & 0.1300 & $0.1991 * * *$ & 0.0800 & 0.1277 & 0.1419 \\
\hline di14 & 0.0451 & 0.0476 & 0.1730 & 0.1204 & 0.0828 & 0.0579 & 0.1417 & 0.1251 \\
\hline di 15 & 0.0236 & 0.0479 & 0.1227 & 0.1648 & 0.0238 & 0.0654 & 0.0964 & 0.1692 \\
\hline
\end{tabular}




\begin{tabular}{|c|c|c|c|c|c|c|c|c|}
\hline di16 & 0.0293 & 0.0505 & 0.1491 & 0.1278 & 0.0635 & 0.0608 & 0.1506 & 0.1420 \\
\hline di17 & $-0.1615^{* * *}$ & 0.0503 & $-0.6230 * * *$ & 0.1585 & $-0.1186^{* *}$ & 0.0614 & $-0.6253 * * *$ & 0.1572 \\
\hline di18 & $-0.1881 * * *$ & 0.0543 & $-0.6401 * * *$ & 0.1816 & $-0.1512 * * *$ & 0.0622 & $-0.6472 * * *$ & 0.1807 \\
\hline di19 & -0.0503 & 0.0735 & -0.1985 & 0.1451 & -0.0487 & 0.0772 & -0.1513 & 0.1451 \\
\hline di 20 & $-0.1371 * * *$ & 0.0517 & $-0.2302 *$ & 0.1374 & $-0.1125^{*}$ & 0.0631 & $-0.2659 * *$ & 0.1409 \\
\hline $\operatorname{di} 21$ & 0.0300 & 0.0485 & -0.0208 & 0.1234 & 0.0321 & 0.0608 & -0.0302 & 0.1317 \\
\hline di 22 & 0.0012 & 0.0458 & 0.1331 & 0.1369 & 0.0139 & 0.0565 & 0.0925 & 0.1441 \\
\hline di 23 & $0.1177 * *$ & 0.0603 & 0.1910 & 0.1292 & 0.1032 & 0.0758 & 0.1740 & 0.1421 \\
\hline di24 & $-0.0782 *$ & 0.0459 & -0.2174 & 0.1562 & -0.0633 & 0.0536 & $-0.3632 * *$ & 0.1532 \\
\hline di 25 & -0.0355 & 0.0466 & 0.0472 & 0.1454 & -0.0021 & 0.0587 & -0.0277 & 0.1523 \\
\hline di26 & 0.0101 & 0.0503 & -0.0514 & 0.1375 & -0.0123 & 0.0522 & -0.1291 & 0.1311 \\
\hline $\mathrm{dt} 2$ (year) & 0.1035 & 0.0721 & 0.0116 & 0.1461 & - & - & - & - \\
\hline $\mathrm{dt} 3$ & -0.0496 & 0.0612 & -0.1071 & 0.1448 & - & - & - & - \\
\hline $\mathrm{dt} 4$ & $-0.1660^{* *}$ & 0.0802 & $-0.4122 * * *$ & 0.1593 & - & - & - & - \\
\hline $\mathrm{dt} 5$ & -0.0433 & 0.0312 & -0.0628 & 0.1297 & - & - & - & - \\
\hline $\mathrm{dt} 6$ & -0.0325 & 0.0347 & $-0.1981 *$ & 0.1126 & - & - & - & - \\
\hline dt7 & -0.0701 & 0.0469 & $-0.2330^{*}$ & 0.1315 & - & - & - & - \\
\hline $\mathrm{dt} 8$ & 0.0012 & 0.0496 & $-0.1924 *$ & 0.1184 & - & - & - & - \\
\hline dt9 & $-0.1261 * *$ & 0.0534 & $-0.3086^{* *}$ & 0.1383 & - & - & - & - \\
\hline $\mathrm{dt} 10$ & -0.0140 & 0.0493 & -0.0454 & 0.1619 & - & - & - & - \\
\hline $\mathrm{dt} 11$ & $-0.0817^{*}$ & 0.0470 & -0.1165 & 0.1104 & - & - & - & - \\
\hline $\mathrm{dt} 12$ & -0.0442 & 0.0426 & -0.0694 & 0.1200 & - & - & - & - \\
\hline $\mathrm{dt} 13$ & -0.0051 & 0.0306 & -0.0102 & 0.0987 & - & - & - & - \\
\hline $\mathrm{dt} 14$ & -0.0146 & 0.0316 & -0.1039 & 0.1020 & - & - & - & - \\
\hline $\mathrm{dt} 15$ & -0.0242 & 0.0340 & -0.0592 & 0.1301 & - & - & - & - \\
\hline $\mathrm{dt} 16$ & $-0.0936 * * *$ & 0.0334 & $-0.2286 * *$ & 0.1118 & - & - & - & - \\
\hline $\mathrm{dt} 17$ & -0.0399 & 0.0297 & -0.1059 & 0.1074 & - & - & - & - \\
\hline $\mathrm{dt} 18$ & -0.0337 & 0.0297 & 0.0014 & 0.1169 & - & - & - & - \\
\hline dt19 & $-0.1041 * *$ & 0.0437 & $-0.2005^{*}$ & 0.1247 & - & - & - & - \\
\hline $\mathrm{dt} 20$ & $-0.0505 * *$ & 0.0267 & -0.1208 & 0.0984 & - & - & - & - \\
\hline $\mathrm{dt} 21$ & $-0.0748 * * *$ & 0.0308 & $-0.2574 * *$ & 0.1080 & - & - & - & - \\
\hline $\mathrm{dt} 22$ & $-0.0727 * * *$ & 0.0282 & -0.2554 & 0.2257 & - & - & - & - \\
\hline $\mathrm{dt} 23$ & $-0.0640 * * *$ & 0.0270 & -0.1817 & 0.1410 & - & - & - & - \\
\hline $\mathrm{dt} 24$ & $-0.0735^{* * *}$ & 0.0278 & $-0.2228^{*}$ & 0.1384 & - & - & - & - \\
\hline $\mathrm{dt} 25$ & $-0.0688 * * *$ & 0.0283 & -0.0756 & 0.1407 & - & - & - & - \\
\hline $\mathrm{dt} 26$ & $-0.0647 * *$ & 0.0322 & -0.0166 & 0.1536 & - & - & - & - \\
\hline $\mathrm{dt} 27$ & $-0.0590 * *$ & 0.0300 & -0.0688 & 0.1662 & - & - & - & - \\
\hline $\mathrm{dt} 28$ & $-0.0509 * *$ & 0.0264 & -0.0775 & 0.1237 & - & - & - & - \\
\hline $\mathrm{dt} 29$ & $-0.0763 * *$ & 0.0370 & -0.0773 & 0.1564 & - & - & - & - \\
\hline
\end{tabular}




\begin{tabular}{|l|r|r|r|r|r|r|r|r|}
\hline $\mathrm{dt30}$ & $-0.0746^{* *}$ & 0.0364 & -0.1685 & 0.1219 & - & - & - & - \\
\hline $\mathrm{dt31}$ & -0.0812 & 0.0556 & -0.1952 & 0.1321 & - & - & - & - \\
\hline $\mathrm{dt32}$ & 0.0597 & 0.0434 & 0.0212 & 0.1366 & - & - & - & - \\
\hline $\mathrm{dt33}$ & $-0.1836^{* *}$ & 0.0798 & $-0.6398 * * *$ & 0.1981 & - & - & - & - \\
\hline $\mathrm{dt34}$ & $-0.8430^{* * *}$ & 0.0660 & $-1.5300^{* * *}$ & 0.1913 & - & - & - & - \\
\hline Trend & - & - & - & - & $0.0079^{* *}$ & 0.0035 & $0.0189^{* *}$ & 0.0094 \\
\hline Trend $^{2}$ & - & - & - & - & $-0.0003 * * *$ & 0.0001 & $-0.0008^{* * *}$ & 0.0003 \\
\hline
\end{tabular}

Notes: Peshmarga, walking, Akre and 1970 are reference occupation, activity, district and years. The asterisks***, ** and * indicate significant at the less than $1 \%, 1-5 \%$ and $6-10 \%$ levels of significance, respectively. 1 . Heteroscedasticity consistentstandard errors. 


\section{Appendix}

Table A: Percentage share of killed and injured and share of killed by gender, 1970-2003.

\begin{tabular}{|c|c|c|c|c|c|c|c|}
\hline \multirow[b]{2}{*}{ Accident Time } & \multicolumn{3}{|c|}{ Number of victims } & \multicolumn{2}{|c|}{ Share of victims } & \multicolumn{2}{|c|}{ Share of killed } \\
\hline & Victims & Killed & Injured & Killed & Injured & Male & Female \\
\hline 1970 & 156 & 124 & 32 & 79.50 & 20.50 & 87.80 & 12.20 \\
\hline 1971 & 6 & 5 & 1 & 83.30 & 16.70 & 83.30 & 16.70 \\
\hline 1972 & 27 & 22 & 5 & 81.50 & 18.50 & 88.90 & 11.10 \\
\hline 1973 & 21 & 16 & 5 & 76.20 & 23.80 & 95.20 & 4.80 \\
\hline 1974 & 213 & 161 & 52 & 75.60 & 24.40 & 91.10 & 8.90 \\
\hline 1975 & 113 & 90 & 23 & 79.60 & 20.40 & 93.80 & 6.20 \\
\hline 1976 & 63 & 52 & 11 & 82.50 & 17.50 & 93.70 & 6.30 \\
\hline 1977 & 49 & 42 & 7 & 85.70 & 14.30 & 98.00 & 2.00 \\
\hline 1978 & 45 & 26 & 19 & 57.80 & 42.20 & 93.30 & 6.70 \\
\hline 1979 & 53 & 46 & 7 & 86.80 & 13.20 & 90.60 & 9.40 \\
\hline 1980 & 72 & 52 & 20 & 72.20 & 27.80 & 90.30 & 9.70 \\
\hline 1981 & 63 & 55 & 12 & 82.10 & 17.90 & 91.00 & 9.00 \\
\hline 1982 & 106 & 91 & 15 & 85.80 & 14.20 & 93.40 & 6.60 \\
\hline 1983 & 125 & 109 & 16 & 87.20 & 12.80 & 87.20 & 12.80 \\
\hline 1984 & 154 & 135 & 19 & 87.70 & 12.30 & 87.00 & 13.00 \\
\hline 1985 & 207 & 160 & 47 & 77.30 & 22.70 & 90.80 & 9.20 \\
\hline 1986 & 316 & 261 & 55 & 82.60 & 17.40 & 90.20 & 9.80 \\
\hline 1987 & 374 & 316 & 58 & 84.50 & 15.50 & 91.40 & 8.60 \\
\hline 1988 & 416 & 342 & 74 & 82.20 & 17.80 & 89.70 & 10.30 \\
\hline 1989 & 209 & 174 & 35 & 83.30 & 16.70 & 92.30 & 7.70 \\
\hline 1990 & 169 & 139 & 30 & 82.20 & 17.80 & 90.50 & 9.50 \\
\hline 1991 & 2,366 & 1,904 & 462 & 80.50 & 19.50 & 87.30 & 12.70 \\
\hline 1992 & 1,306 & 1,120 & 186 & 85.80 & 14.20 & 92.60 & 7.40 \\
\hline 1993 & 986 & 859 & 127 & 87.10 & 12.90 & 93.20 & 6.80 \\
\hline 1994 & 979 & 830 & 149 & 84.80 & 15.20 & 92.20 & 7.80 \\
\hline 1995 & 945 & 814 & 131 & 86.10 & 13.90 & 91.60 & 8.40 \\
\hline 1996 & 935 & 766 & 169 & 81.90 & 18.10 & 91.00 & 9.00 \\
\hline 1997 & 792 & 665 & 127 & 84.00 & 16.00 & 93.70 & 6.30 \\
\hline 1998 & 633 & 533 & 100 & 84.20 & 15.80 & 95.10 & 4.90 \\
\hline 1999 & 464 & 359 & 105 & 77.40 & 22.60 & 92.50 & 7.50 \\
\hline 2000 & 102 & 76 & 26 & 74.50 & 25.50 & 90.20 & 9.80 \\
\hline 2001 & 138 & 135 & 3 & 97.80 & 2.20 & 94.20 & 5.80 \\
\hline 2002 & 180 & 94 & 86 & 52.20 & 47.80 & 91.10 & 8.90 \\
\hline 2003 & 87 & 10 & 77 & 11.50 & 88.50 & 98.90 & 1.10 \\
\hline
\end{tabular}


Table B: Percentage share of killed among Occupations Groups

\begin{tabular}{|c|c|c|c|c|c|c|c|c|}
\hline Accident Time & Killed & Peshmarga & Child & Unemployed & Shepherd & Farmer & Driver & Others \\
\hline 1970 & 79.50 & 16.70 & 20.50 & 6.40 & 20.50 & 34.00 & 1.90 & 0.00 \\
\hline 1971 & 83.30 & 16.70 & 0.00 & 16.70 & 50.00 & 16.70 & 0.00 & 0.00 \\
\hline 1972 & 81.50 & 11.10 & 22.20 & 7.40 & 3.70 & 51.90 & 3.70 & 0.00 \\
\hline 1973 & 76.20 & 0.00 & 19.00 & 4.80 & 14.30 & 57.10 & 0.00 & 4.80 \\
\hline 1974 & 75.60 & 29.10 & 9.90 & 6.60 & 11.70 & 39.00 & 3.80 & 0.00 \\
\hline 1975 & 79.60 & 14.20 & 12.40 & 5.30 & 18.60 & 44.20 & 5.30 & 0.00 \\
\hline 1976 & 82.50 & 1.60 & 14.30 & 6.30 & 28.60 & 46.00 & 3.20 & 0.00 \\
\hline 1977 & 85.70 & 8.20 & 22.40 & 4.10 & 18.40 & 42.90 & 4.10 & 0.00 \\
\hline 1978 & 57.80 & 15.60 & 40.00 & 6.70 & 11.10 & 24.40 & 2.20 & 0.00 \\
\hline 1979 & 86.80 & 17.00 & 18.90 & 5.70 & 35.80 & 22.60 & 0.00 & 0.00 \\
\hline 1980 & 72.20 & 20.80 & 25.00 & 5.60 & 13.90 & 31.90 & 2.80 & 0.00 \\
\hline 1981 & 82.10 & 20.90 & 19.40 & 3.00 & 11.90 & 43.30 & 1.50 & 0.00 \\
\hline 1982 & 85.80 & 30.20 & 15.10 & 4.70 & 15.10 & 25.50 & 9.40 & 0.00 \\
\hline 1983 & 87.20 & 15.20 & 29.60 & 12.80 & 8.80 & 27.20 & 5.60 & 0.80 \\
\hline 1984 & 87.70 & 14.30 & 29.20 & 9.70 & 11.70 & 29.90 & 5.20 & 0.00 \\
\hline 1985 & 77.30 & 21.30 & 17.90 & 7.70 & 17.40 & 31.40 & 4.30 & 0.00 \\
\hline 1986 & 82.60 & 25.00 & 13.90 & 9.20 & 13.30 & 35.40 & 3.20 & 0.00 \\
\hline 1987 & 84.50 & 20.30 & 23.50 & 7.50 & 9.60 & 35.00 & 4.00 & 0.00 \\
\hline 1988 & 82.20 & 20.20 & 17.10 & 7.70 & 10.60 & 38.20 & 6.30 & 0.00 \\
\hline 1989 & 83.30 & 16.70 & 23.40 & 6.20 & 15.80 & 32.10 & 5.70 & 0.00 \\
\hline 1990 & 82.20 & 12.40 & 20.70 & 10.10 & 18.30 & 32.50 & 5.90 & 0.00 \\
\hline 1991 & 80.50 & 8.90 & 34.80 & 10.20 & 5.00 & 37.30 & 3.70 & 0.10 \\
\hline 1992 & 85.80 & 8.70 & 23.50 & 8.00 & 12.90 & 43.80 & 3.10 & 0.10 \\
\hline 1993 & 87.10 & 6.80 & 20.40 & 6.60 & 15.00 & 47.30 & 3.80 & 0.20 \\
\hline 1994 & 84.80 & 10.80 & 20.70 & 6.60 & 13.50 & 45.60 & 2.60 & 0.20 \\
\hline 1995 & 86.10 & 12.50 & 21.70 & 7.60 & 12.20 & 43.40 & 2.60 & 0.00 \\
\hline 1996 & 81.90 & 11.70 & 27.00 & 6.80 & 14.10 & 36.40 & 4.00 & 0.10 \\
\hline 1997 & 84.00 & 17.70 & 19.70 & 6.70 & 15.20 & 37.90 & 2.90 & 0.00 \\
\hline 1998 & 84.20 & 21.60 & 19.30 & 5.40 & 15.30 & 35.50 & 2.80 & 0.00 \\
\hline 1999 & 77.40 & 19.20 & 25.00 & 6.30 & 22.60 & 22.40 & 4.50 & 0.00 \\
\hline 2000 & 74.50 & 7.80 & 35.30 & 5.90 & 17.60 & 26.50 & 6.90 & 0.00 \\
\hline 2001 & 97.80 & 4.30 & 27.50 & 4.30 & 23.90 & 34.10 & 5.10 & 0.70 \\
\hline 2002 & 52.20 & 20.00 & 20.00 & 10.00 & 20.60 & 25.00 & 3.30 & 1.10 \\
\hline 2003 & 11.50 & 4.60 & 13.80 & 4.60 & 14.90 & 43.70 & 12.60 & 5.70 \\
\hline
\end{tabular}


Table C: Percentage share of killed among Activity at time of Accident

\begin{tabular}{|r|r|r|r|r|r|r|r|}
\hline Accident Time & \multicolumn{1}{l|}{ Killed } & \multicolumn{1}{l|}{ Walk } & \multicolumn{1}{l|}{ Touch } & \multicolumn{1}{l|}{ Collect } & \multicolumn{1}{l|}{ Fight } & \multicolumn{1}{l|}{ Fire } & \multicolumn{1}{l|}{ Others } \\
\hline 1970 & 79.50 & 32.10 & 32.10 & 22.40 & 3.20 & 1.30 & 9.00 \\
\hline 1971 & 83.30 & 16.70 & 50.00 & 33.30 & 0.00 & 0.00 & 0.00 \\
\hline 1972 & 81.50 & 18.50 & 55.60 & 18.50 & 0.00 & 7.40 & 0.00 \\
\hline 1973 & 76.20 & 14.30 & 61.90 & 14.30 & 0.00 & 0.00 & 9.50 \\
\hline 1974 & 75.60 & 34.30 & 25.40 & 21.60 & 6.10 & 0.00 & 12.70 \\
\hline 1975 & 79.60 & 37.20 & 21.20 & 27.40 & 3.50 & 1.80 & 8.80 \\
\hline 1976 & 82.50 & 17.50 & 55.60 & 22.20 & 1.60 & 0.00 & 3.20 \\
\hline 1977 & 85.70 & 26.50 & 24.50 & 32.70 & 0.00 & 2.00 & 14.30 \\
\hline 1978 & 57.80 & 44.40 & 28.90 & 22.20 & 0.00 & 0.00 & 4.40 \\
\hline 1979 & 86.80 & 34.00 & 20.80 & 45.30 & 0.00 & 0.00 & 0.00 \\
\hline 1980 & 72.20 & 31.90 & 26.40 & 20.80 & 1.40 & 4.20 & 15.30 \\
\hline 1981 & 82.10 & 43.30 & 25.40 & 11.90 & 4.50 & 1.50 & 13.40 \\
\hline 1982 & 85.80 & 28.30 & 30.20 & 24.50 & 6.60 & 0.00 & 10.40 \\
\hline 1983 & 87.20 & 28.80 & 31.20 & 21.60 & 3.20 & 4.00 & 11.20 \\
\hline 1984 & 87.70 & 34.40 & 29.90 & 18.80 & 2.60 & 1.90 & 12.30 \\
\hline 1985 & 77.30 & 27.10 & 28.00 & 24.60 & 4.30 & 0.50 & 15.50 \\
\hline 1986 & 82.60 & 35.40 & 25.60 & 20.30 & 4.70 & 1.30 & 12.70 \\
\hline 1987 & 84.50 & 37.70 & 24.90 & 20.60 & 2.70 & 2.70 & 11.50 \\
\hline 1988 & 82.20 & 45.00 & 23.80 & 15.10 & 2.20 & 1.70 & 12.30 \\
\hline 1989 & 83.30 & 29.70 & 34.40 & 27.30 & 1.90 & 1.00 & 5.70 \\
\hline 1990 & 82.20 & 30.20 & 21.90 & 37.30 & 0.00 & 0.60 & 10.10 \\
\hline 1991 & 80.50 & 37.00 & 35.00 & 16.10 & 1.10 & 1.60 & 9.30 \\
\hline 1992 & 85.80 & 26.80 & 34.60 & 29.60 & 1.80 & 2.10 & 5.00 \\
\hline 1993 & 87.10 & 23.90 & 33.30 & 34.10 & 1.60 & 1.60 & 5.50 \\
\hline 1994 & 84.80 & 26.00 & 32.60 & 33.60 & 0.80 & 1.00 & 5.90 \\
\hline 1995 & 86.10 & 27.10 & 30.10 & 31.60 & 1.50 & 1.50 & 8.30 \\
\hline 1996 & 81.90 & 22.10 & 35.90 & 29.90 & 1.80 & 2.00 & 8.10 \\
\hline 1997 & 84.00 & 28.20 & 31.80 & 27.30 & 3.50 & 3.20 & 6.10 \\
\hline 1998 & 84.20 & 21.60 & 31.90 & 26.50 & 6.50 & 2.20 & 11.20 \\
\hline 1999 & 77.40 & 20.70 & 36.90 & 27.40 & 3.90 & 1.70 & 9.50 \\
\hline 2000 & 74.50 & 20.60 & 45.10 & 19.60 & 0.00 & 2.90 & 11.80 \\
\hline 2001 & 97.80 & 9.40 & 39.90 & 25.40 & 0.70 & 9.40 & 15.20 \\
\hline 2002 & 52.20 & 12.20 & 31.10 & 35.00 & 7.80 & 2.80 & 11.10 \\
\hline 2003 & 11.50 & 0.00 & 8.00 & 88.50 & 2.30 & 1.10 & 0.00 \\
\hline & & & & & & & \\
\hline
\end{tabular}


Table D: Population, victims and victims killed and injured per 1000 inhabitants by districts.

\begin{tabular}{|c|c|c|c|c|c|c|c|c|}
\hline & \multicolumn{3}{|c|}{ Population } & \multicolumn{3}{|c|}{ Fatalities } & \multicolumn{2}{|c|}{ Fatalities per 1000} \\
\hline District & Male & Female & Total & Injured & Killed & Total & Injured & Killed \\
\hline Akre & 102,794 & 97,885 & 200,679 & 20 & 70 & 90 & 0.10 & 0.35 \\
\hline Amedi & 51,929 & 49,979 & 101,908 & 46 & 329 & 375 & 0.45 & 3.23 \\
\hline Chamchamal & 65,659 & 67,857 & 133,516 & 26 & 321 & 347 & 0.19 & 2.40 \\
\hline Choman & 18,533 & 18,185 & 36,718 & 175 & 769 & 944 & 4.77 & 20.94 \\
\hline Darbandikhan & 21,672 & 21,897 & 43,569 & 12 & 443 & 455 & 0.28 & 10.17 \\
\hline DashtiHawler & 65,835 & 65,298 & 131,133 & 86 & 100 & 186 & 0.66 & 0.76 \\
\hline Duhok & 142,330 & 136,977 & 279,307 & 57 & 120 & 177 & 0.20 & 0.43 \\
\hline Dukan & 29,089 & 30,045 & 59,134 & 212 & 197 & 409 & 3.59 & 3.33 \\
\hline Erbil & 614,389 & 604,523 & $1,218,912$ & 117 & 324 & 441 & 0.10 & 0.27 \\
\hline Halabja & 50,439 & 51,737 & 102,176 & 38 & 800 & 838 & 0.37 & 7.83 \\
\hline Kalar & 78,756 & 78,144 & 156,900 & 4 & 488 & 492 & 0.03 & 3.11 \\
\hline Khabat & 32,873 & 32,103 & 64,976 & 1 & 0 & 1 & 0.02 & 0.00 \\
\hline Khanaqin & .. & .. & .. & 5 & 218 & 223 & & .. \\
\hline Kifri & 18,418 & 18,585 & 37,003 & 8 & 161 & 169 & 0.22 & 4.35 \\
\hline Koye & 58,728 & 56,639 & 115,367 & 11 & 300 & 311 & 0.10 & 2.60 \\
\hline Makhmur & .. & .. & .. & 1 & 0 & 1 & .. & .. \\
\hline Mergasur & 31,286 & 32,231 & 63,517 & 40 & 201 & 241 & 0.63 & 3.16 \\
\hline Penjwin & 24,396 & 24,358 & 48,754 & 91 & 1,010 & 1,101 & 1.87 & 20.72 \\
\hline Pishdar & 59,681 & 60,257 & 119,938 & 380 & 620 & 1,000 & 3.17 & 5.17 \\
\hline Rania & 105,367 & 108,538 & 213,905 & 188 & 215 & 403 & 0.88 & 1.01 \\
\hline Semel & 55,414 & 53,129 & 108,543 & 9 & 31 & 40 & 0.08 & 0.29 \\
\hline Shaqlawa & 76,502 & 74,456 & 150,958 & 131 & 288 & 419 & 0.87 & 1.91 \\
\hline Sharazur & 74,869 & 75,579 & 150,448 & 5 & 173 & 178 & 0.03 & 1.15 \\
\hline Sharbazher & 10,570 & 10,526 & 21,096 & 171 & 1,241 & 1,412 & 8.11 & 58.83 \\
\hline Shekhan & 36,343 & 35,404 & 71,747 & 6 & 46 & 52 & 0.08 & 0.64 \\
\hline Soran & 120,920 & 117,185 & 238,105 & 242 & 870 & 1,112 & 1.02 & 3.65 \\
\hline Suleimaniyah & 408,907 & 422,588 & 831,495 & 167 & 934 & 1,101 & 0.20 & 1.12 \\
\hline Zakho & 107,546 & 103386 & 210,932 & 41 & 305 & 346 & 0.19 & 1.45 \\
\hline
\end{tabular}


Figure A1: Number of killed and injured, 1970-2003.

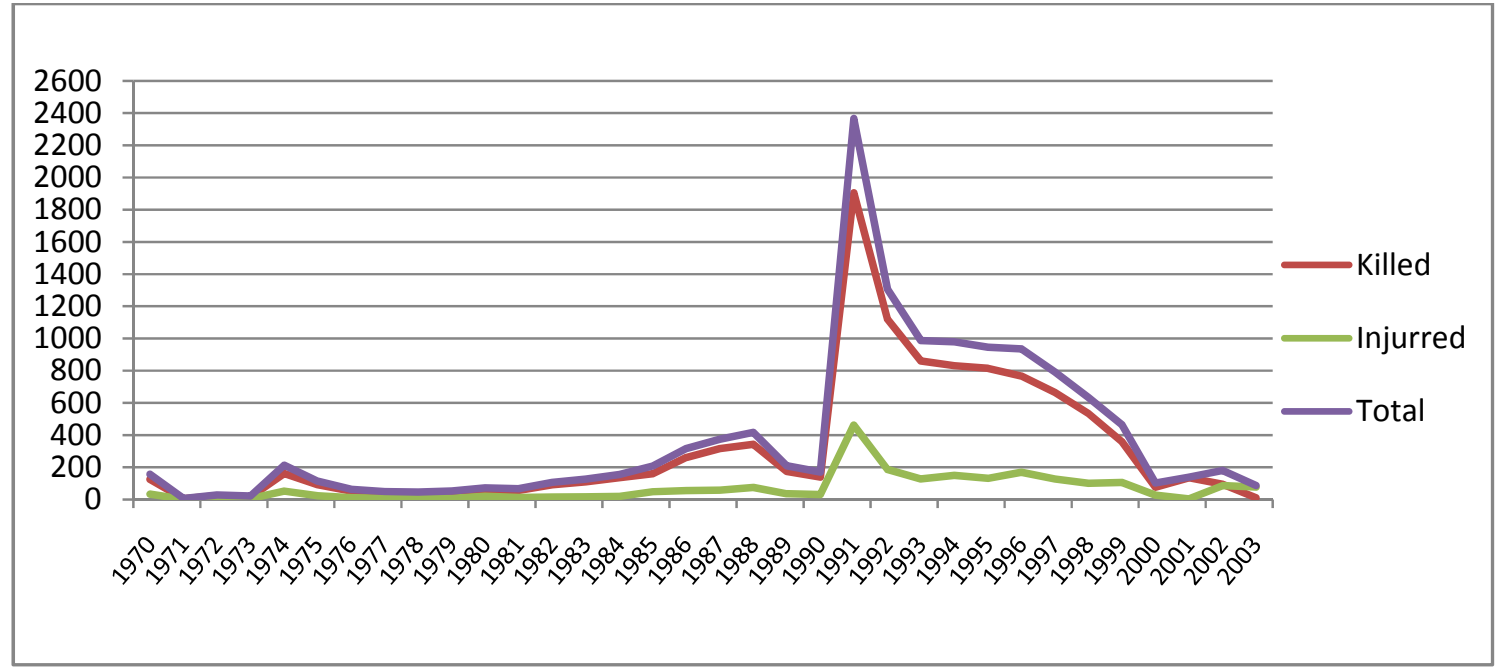

Figure A2: Number of killed (male) and injured (female) by gender, 1970-2003.

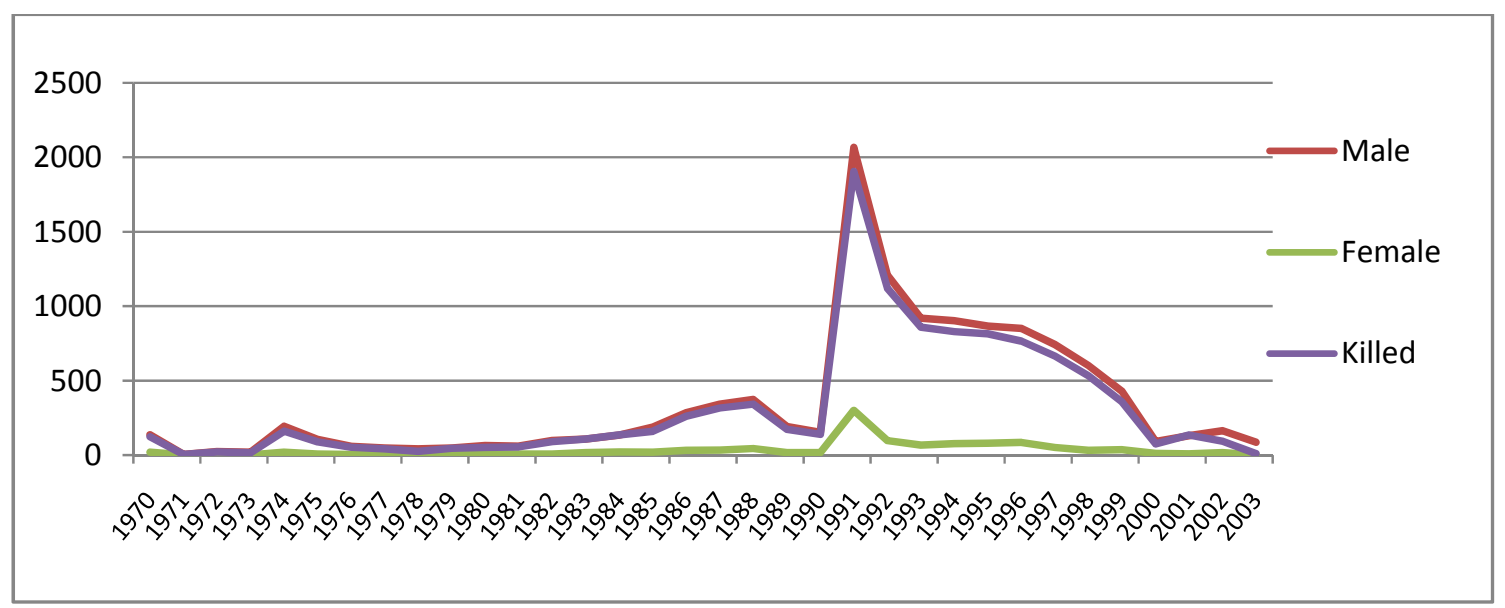

Figure A3: Share of killed and injured, 1970-2003.

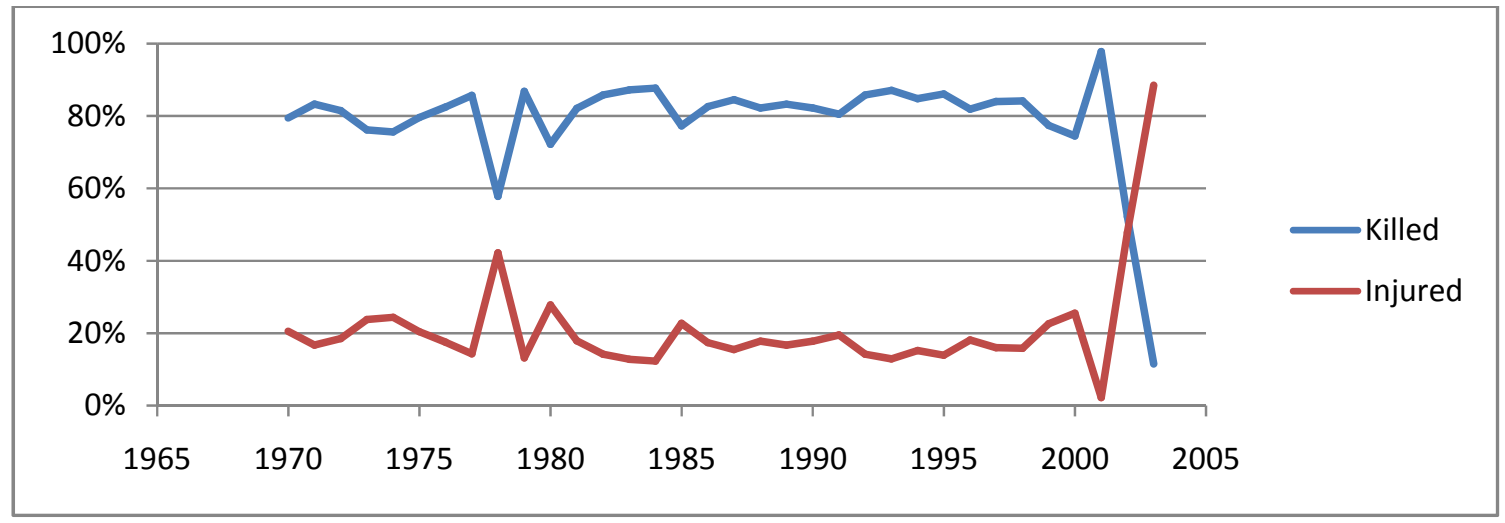


Figure B1: Share of killed among different occupation groups (peshmarga, child, unemployed, shepherd, farmer, driver, others), 1970-2003.

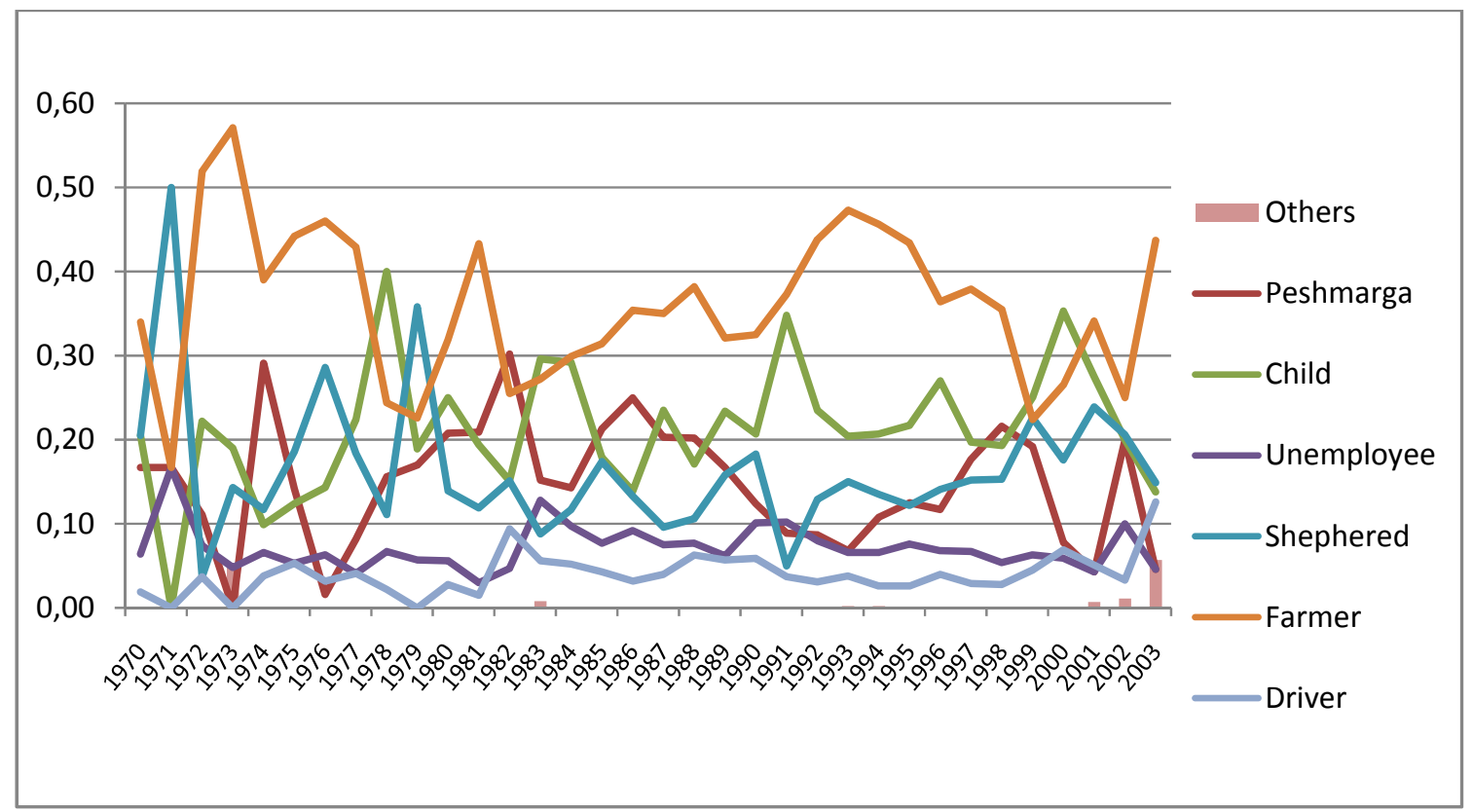

Figure B2: Number of killed among different occupation groups (peshmarga, child, unemployed, shepherd, farmer, driver, others), 1970-2003.

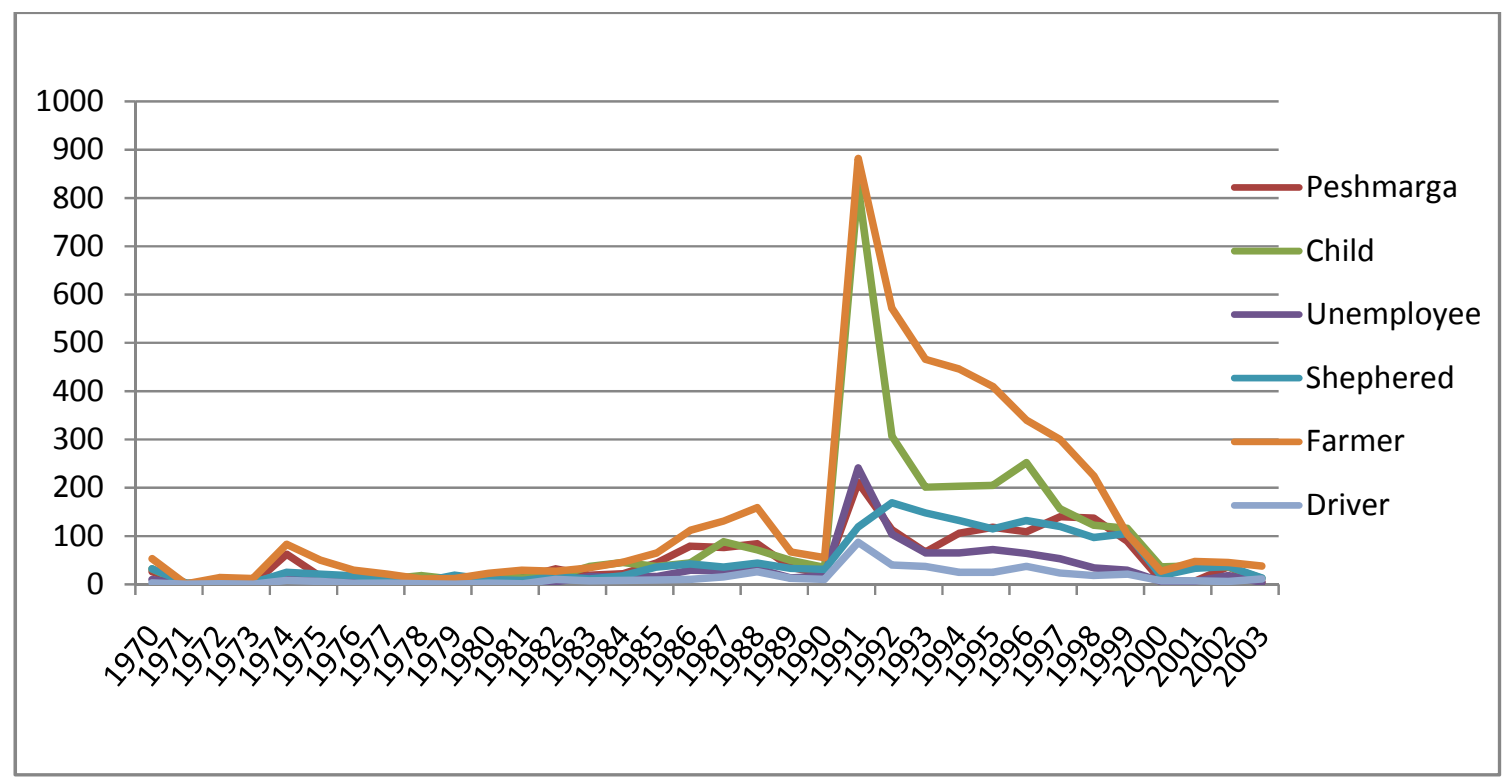


Figure C1: Share of killed among different activity groups (walking, touching, collecting, fighting, fire, other activities) at the time of accident, 1970-2003.

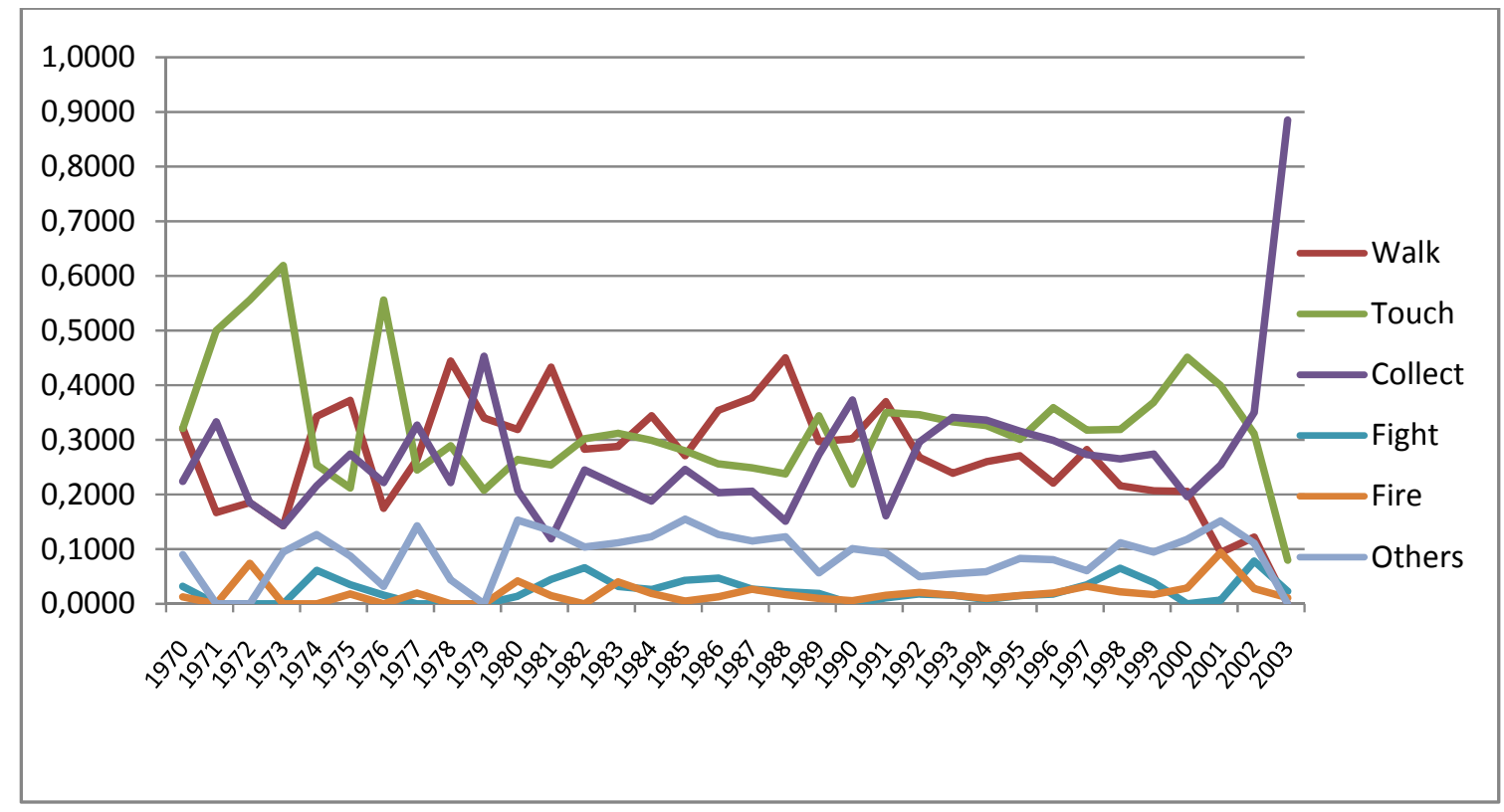

Figure C2: Number of killed among different activity groups (walking, touching, collecting, fighting, fire, others) at the time of accident, 1970-2003.

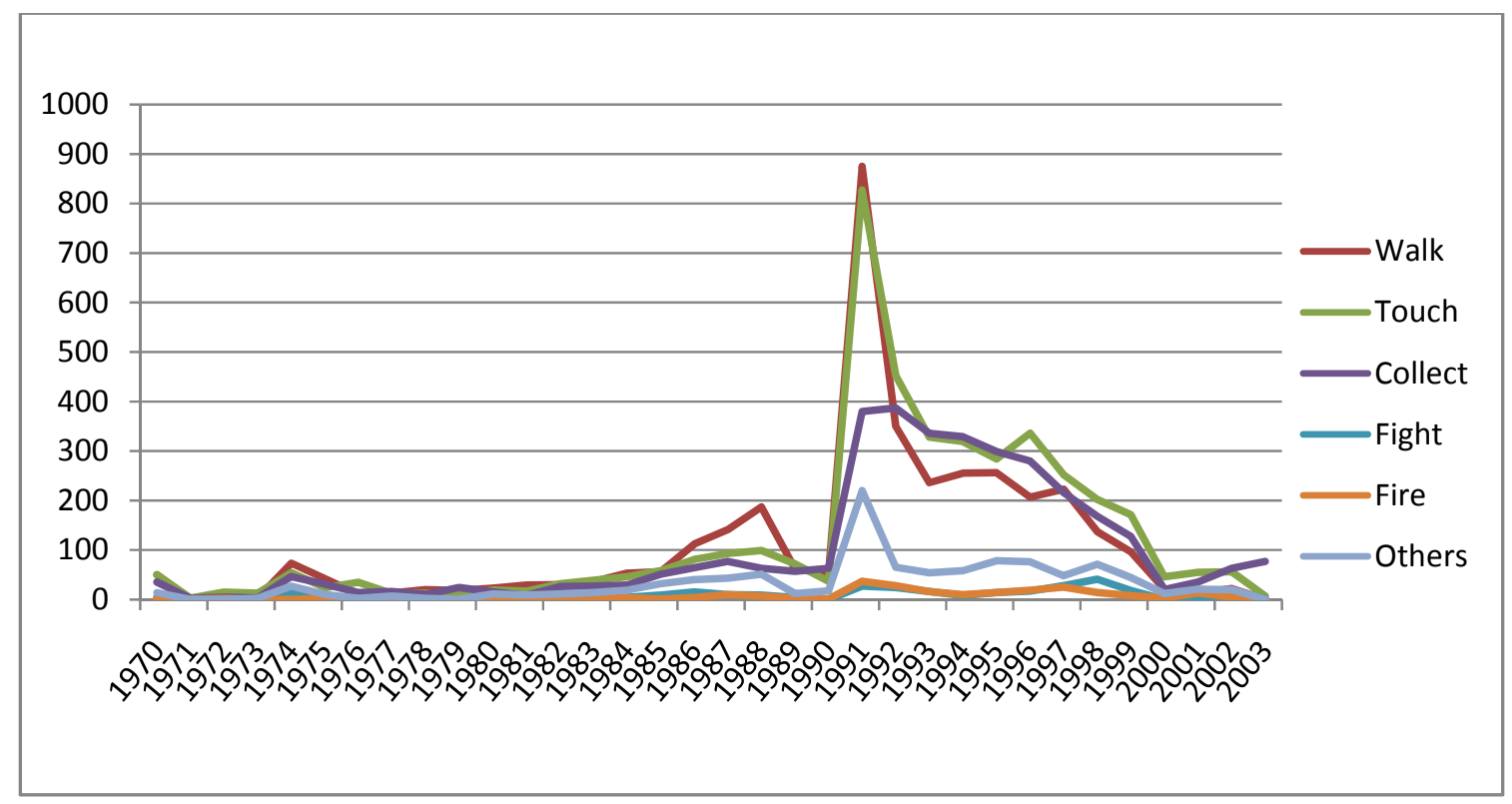


Figure D1: Share of killed aware of danger (danger) and participating in mine awareness programs (mre), 1970-2003.

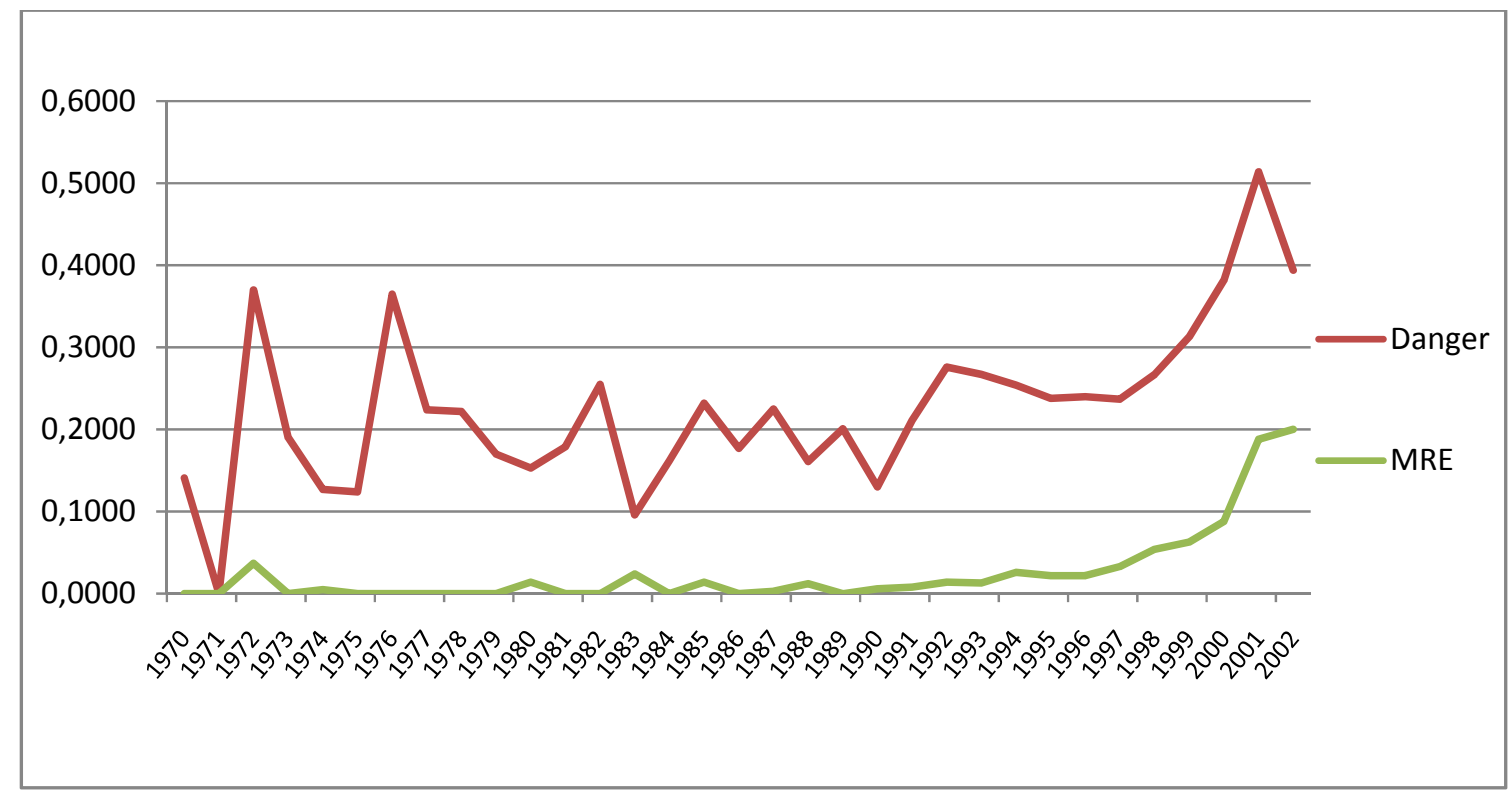

Figure D2: Number of killed aware of danger (danger) and participating in mine awareness programs (mre), 1970-2003.

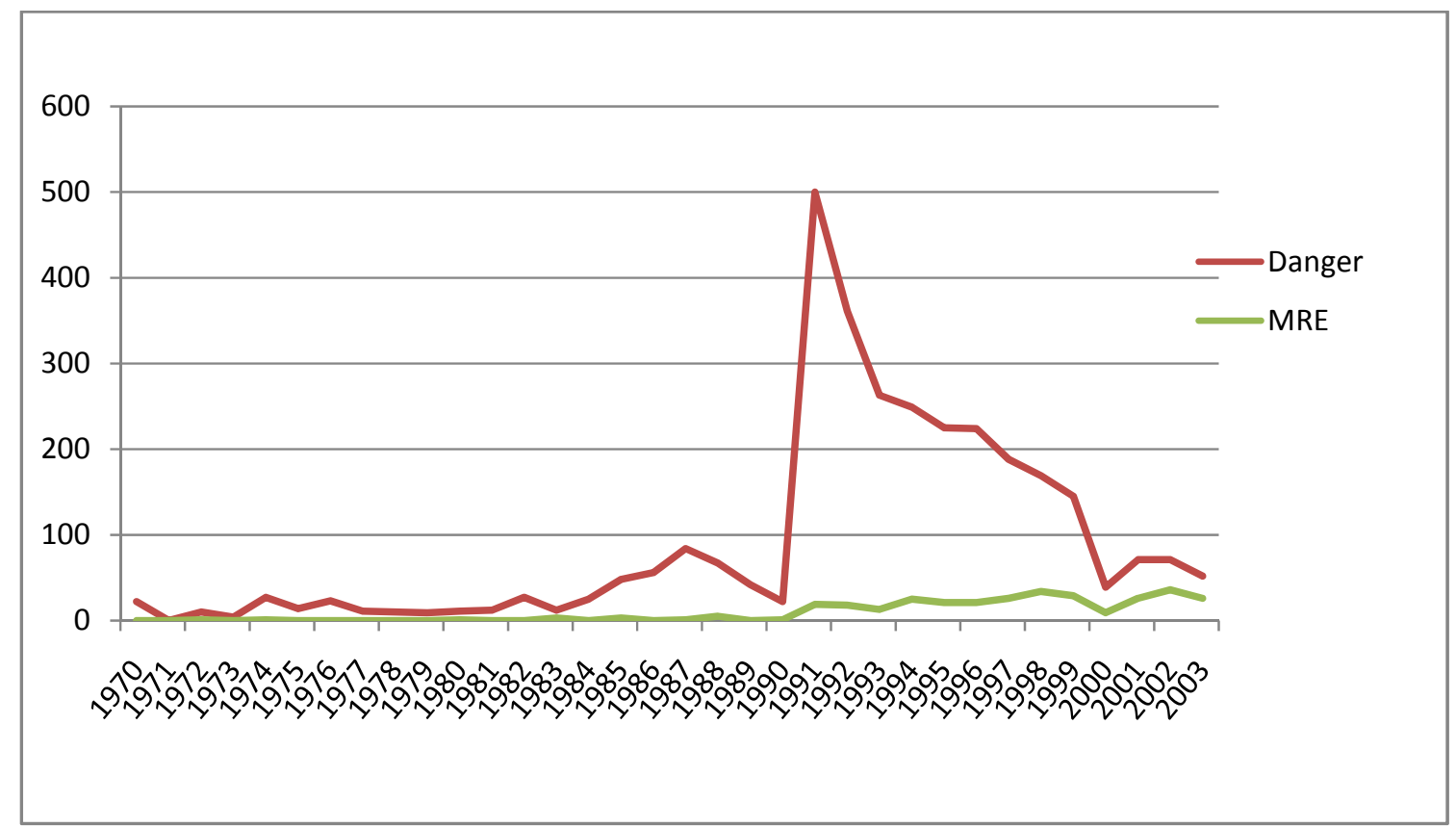

